Folk Stories of the Tempassuk and Tuaran Districts, British North Borneo.

Author(s): Ivor H. N. Evans

Source: The Journal of the Royal Anthropological Institute of Great Britain and Ireland, Vol. 43

(Jul. - Dec., 1913), pp. 422-479

Published by: Royal Anthropological Institute of Great Britain and Ireland

Stable URL: http://www.jstor.org/stable/2843543

Accessed: 08-02-2016 23:59 UTC

Your use of the JSTOR archive indicates your acceptance of the Terms \& Conditions of Use, available at http://www.jstor.org/page/ info/about/policies/terms.jsp

JSTOR is a not-for-profit service that helps scholars, researchers, and students discover, use, and build upon a wide range of content in a trusted digital archive. We use information technology and tools to increase productivity and facilitate new forms of scholarship. For more information about JSTOR, please contact support@jstor.org. 


\title{
FOLK STORIES OF THE TEMPASSUK AND TUARAN DISTRICTS, BRITISH NORTH BORNEO.
}

\author{
By Ivor H. N. Evans \\ (Late of the British North Borneo Company's Service).
}

INTRODUCTION.

THE present collection of Dusun, Bajau, and Illanun stories was made during the years 1910 and 1911, during which the writer was stationed in the two adjoining districts of the Tuaran and Tempassuk. The Tempassuk is inhabited by three different tribes, the Dusun, Bajau, and Illanun, and it is chiefly from the first of these that the tales have been collected; for since both the Illanun and Bajau are Mohammedans, their folk-lore is not nearly so extensive as that of their Dusun neighbours, who have only a hazy religious belief. The Bajau and Illanun, roughly speaking, form the coastal and estuarine population, while the Dusun, with the exception of those of a few large kampongs (villages) on the plains, which border on the Bajau zone, are confined to the foothills and mountainous portions of the district. [A map of the whole area is included which has been coloured roughly according to the tribal divisions.] The Tuaran District is also divided between Bajau and Dusun, but here Illanun are wanting. It would seem that the Dusun are the original inhabitants of the country and that the Bajau and Illanun, both proto-Malayan tribes, are later arrivals who have driven the firstnamed inland. This is known to be a fact in the case of the Illanun, who are a piratical people of Mindanaho in the Philippines; of whom small roving parties have settled in Borneo. The origin of the Bajau is, I believe, unknown, but they are widely spread along the coasts of North Borneo. However, as far as the Tempassuk is concerned, tradition asserts that they first came in trading prahus from the direction of Kudat, and eventually fought the Dusun and formed settlements in the country. It is often said by residents in North Borneo, seemingly without sufficient evidence, that the Dusun have a very large admixture of Chinese blood. What the Dusun would seem to be is a primitive Indonesian people, with possibly some slight strain of Mongolian (not modern Chinese) blood. The up-country Dusun is generally short, sturdy and light in colour, with a face that is often broad and flat, showing great development of the angle of the jaw. The nose is broad and the bridge and root depressed. The head is long as compared with that of the Bajau. The writer has made frequent inquiries as to legends of a small black race (Negritos) having inhabited the districts in former times, but has always been answered 
by the natives that nothing of the sort has been heard of. Stone implements occur, but whether they were made by the ancestors of the present Dusun or not, it seems at present impossible to say. If any of the stories should appear to be somewhat vague to the reader, the writer hopes that he will ascribe it to the want of clearness of the Dusun narrator. The legends as well as the language of the district often vary from village to village, and consequently a legend well known to all the people of one village will often be totally unknown to those of another. Such legends as that of the Creation are, however, common to both the Tempassuk and Tuaran Districts, but are subject to local variations.

NoTE.-All the stories are taken down straight from the Malay, which is the lingua franca of the country.

\section{Legend of The CReation.}

A version told by Gensiou, a Low-Country Dusun of Kampong Tempassuk, Tempassuk District.

When the world was first made there was only water with a great rock in it: a man and a woman were on the rock. The man and the woman were dirty and went down to bathe in the water, and when they bathed the dirt rolled off from. their bodies. They smelled the dirt which came from them and the man said, "This will become land," and it became land. Then the man and woman made a stone in the shape of a man but the stone could not talk, so they made a wooden figure and when it was made it talked, though not long after it became worn out and rotten; afterwards they made a man of earth, and people are descended from this till the present day and from the other earthmen which they made at the same time. The man and the woman began to think in what way they could give food to their men, but they could not get anything, as there was no food in the world. Then the woman gave birth to a child, and the man said to the woman, "How are we to give food to our men?" The woman wanted to kill the child. So they killed it and when they had cut it to bits they planted it in the ground; after a time its blood gave rise to padi, ${ }^{1}$ its head to a coconut, its fingers to pinang, ${ }^{2}$ its ears to the sireh vine, its feet to jagong, ${ }^{3}$ its skin to a gourd vine and the rest of its body to other things good to eat. Its throat also became sugar cane and its knees kaladi (yams).

\section{The Kandowei and the Kerbau (Buffalo).}

Told by Anggor, a Tuaran Dusun.

NotE.-The Kandowei is the white padi bird (Bubulcus coromandus) which so often accompanies herds of buffalo.

The bird said to the buffalo; "If I were to drink the water of a stream I could drink it all." "I also," said the Kerbau, "could finish it, for I an big while you
1 Rice.
2 Betel nut.
3 Indian corn. 
are small." "Very well," said the bird, "to-morrow we will drink." In the morning, when the water was coming down in flood the bird told the buffalo to drink first. The Kerbau drank and drank but the water only came down the faster and at length he was forced to stop, so the Kerbau said to the bird, "You can take my place and try, for I cannot finish." Now the Kandowei waited till the flood had gone down, and when it had done so he put his beak into the water and pretended to drink. Then he waited till all the water had run away out of the stream and said to the Kerbau, "See, I have finished it !" And since the bird outwitted the Kerbau in this manner, the Kerbau has become his slave and the bird rides on his back.

\section{Kenharingan AND Bisagit.}

\section{Told by Anggor, a Tuaran Dusun.}

Kenharingan made all men and the earth. First of all he made the earth, and the earth would, not become hard. Then he ordered the Torepos ${ }^{1}$ to fly to Bisagit, the Spirit of Small-pox, and ask for earth. The bird flew to Bisagit's country and when it came there it said to him, "Kenharingan has ordered me to come and ask for earth from here." Said Bisagit, "You can have earth from here if Kenharingan will promise to divide his men with me, half for me and half for Kenharingan." “Wait," said the bird, “and I will fly back to Kenharingan and ask for orders, for I have no power to make the agreement." So the Torepos flew back to the country of Kenharingan and, going up into his house, said to him, "I have been to Bisagit's country and asked Orang Tua Bisagit if he will give earth, but he said, 'I will only give earth if Kenharingan will share his men with me.'” "Very well," said Kenharingan, "I will share my men with him. Fly back and ask for earth and say to Bisagit that with regard to his wanting half my men I will agree to it if he will give me earth." The Torepos went back to Bisagit's country and told him Kenharingan's words. Then said Bisagit, "Kenharingan has acknowledged this?" and the Torepos said, "He has." So Bisagit got earth and gave it to the bird, saying, "Take this earth and go back." The bird came again to Kenharingan's country and said to him, "I have got the earth," and Kenharingan said, "Well done." In the morning early Kenharingan put Bisagit's earth into the middle of his own and immediately the land became hard, and when it had become hard he made men. Two or three years afterwards Bisagit came and asked for his men, and all Kenharingan's men fell ill of small-pox, half the men died and half lived. Those who died followed Bisagit, and those who lived followed Kenharingan. When Bisagit was going home, he said to Kenharingan, "I am going home, but at the end of forty years I will come back and ask for more men." "Very well," said Kenharingan, " but do not kill all my men, for if you kill all I shall have no kampong2 left." And up to the present time Bisagit comes once in forty years

1. Small green parrot.

${ }^{2}$ Viilage. 
and takes his toll of one-half of all Kenharingan's men. Kenharingan said to his men, "I am going back to my country in the sky; if there is fever or other disease in your kampong you must menghadji and you will gain relief."

The Dusun of Tuaran do not menghadji for small-pox as it is useless, since there is an agreement between Kenharingan and Bisagit that small-pox shall come once in forty years and carry off half of Kenharingan's men.

\section{The Legend of the Limpada.}

Told by Orang Tua Lengok of K. Bengkahak, Tempassuk District.

Long ago there was a house in which lived a man and his wife, and near the house was a limpada tree. Whenever fruit fell from the tree, the man and his wife heard a noise like that of a child weeping. His wife was afraid at the sound of the wailing, and the man descended from his house, but he only saw the fruits which had fallen to the ground. One of these he pushed with his parangl and again he heard a sound of weeping, so taking his parang he cut it in two. When he had opened it there was nothing but earth inside. He went back to the house and that night as he slept with his wife a man came to him in his dream and said, "Why have you cut me? I will be revenged upon you." Then the man spoke and said, "Do not, I pray you, for I did not see anyone when I cut open the fruit, but I only heard the sound of a child crying." The dream man said to him, "Very well, to-morrow you shall see me." The next morning the man saw a beautiful youth, dressed in magnificent clothes, walking below the limpada tree. On the following night the man slept and dreamed again and the dream man said to him as before, "I will be revenged upon you." "Do not, I pray you," said the man. "Well," said the dream man, "I will make a contract with you. : Do not damage this tree, do not walk underneath it, do not eat its fruit. If you go under the tree and take its fruit I will afflict you with ulcers until you die."

Now the man who came in the dream was Kenharingan and the tree is his.

NoтE.-The limpada, a tree with large leaves and big shiny red fruits with a smooth skin, is looked upon with reverence by the Dusun of the Tempassuk. If they find one when they are clearing a patch of jungle for padi-planting it is either left standing or a religious ceremony must be gone through before it can be cut down. The belief that bad ulcers are caused by going near the limpada is very general. I have made inquiries, but have not been able to hear that this legend is known around Tuaran.

\section{The Making of the Bluntong (Rainbow).}

Told by Sirinan (Low-Country Dusun) of K. Piasau, Tempassuk District.

Long ago the rainbow was a path for men. Those who lived up country used the rainbow as a bridge when they wished to go down country in search of wives.

1 Chopping knife. 
For though there were women up country the up country men were very fond of the down country women. Because of the men's desire for wives from the coast they made the rainbow as a bridge and you can see the floor and hand rail of the bridge in the rainbow to the present day. The men when they had first made the rainbow walked on it to the women's houses. When the men had fed, the women followed the men along the rainbow to their homes. When they arrived up country the marriages were celebrated with a feast and the men became drunk. Then came a head man from another kampong and said to them, "You men are very clever, how long have I lived in this country but never yet have I seen anything like your rainbow. Do you intend to leave it there or not?" The men replied, "When we want to go down country with our wives we will put it in place, but when we do not want it we will take it away," and thus they do to the present day. What the men were I do not know, but they were more than ordinary men. It is an old tíme tale of our people. Perhaps it is true, as just now, as you saw, the rainbow vanished.

\section{Kenharingan AND the SNake.}

A slightly different version told by Sirinan Orang Tua of K. Piasau, Tempassuk District.

Kenharingan once pounded rice and made flour from it. When he had made the flour he called all the animals in the world and ordered them to eat it. When they had all got their mouths full and could not speak, Kenharingan asked them "Who can cast off his skin?" Now the snake had only been putting his mouth into the flour and pretending to eat, and being able to answer because his mouth was not full he said, "I can." "Very well," said Kenharingan, "if that is so you shall not die," so until the present day the snake does not die unless killed by man.

\section{The Tompok and the Sungkial.}

Told by Sirinan (Low-Country Dusun) of K. Piasau, Tempassuk District.

NotE.-Various old jars, probably all of which are of Chinese manufacture, are worshipped by the Dusun as the habitations of various spirits. The Tompok, the Narajang, and the Gusi, three kinds of jars, are believed to contain evil spirits, the Sungkiel is inhabited by a beneficent spirit. Jar worship, especially that of the Gusi, is very prevalent among the Low-Country Dusun of the Tuaran District and $\$ 2,000$ to $\$ 3,000$ is by no means an unusual price to pay for a single jar. The Tempassuk Dusun say that there were formerly spirit jars in their district, but that they have now nearly all been sold to Brunei traders who have again sold them to the natives of Tuaran, Papar, and other places. "For," say the Tempassuk Dusun, "we 
preferred the money to a jar which contained an evil spirit and which demanded constant sacrifices." Only a few Sungkiel jars are now left in the district.

There was once a man who was very rich and had all kinds of goods. After a time he took a wife, but no child came of the marriage for two or three years. Then said the man, "How is it that we have no children while others who were married at the same time all have some." One night the man dreamed that a woman appeared in his room and that he said to the woman of his dream, "Why have we no children?" The woman replied, "You have no children because you have so many possessions. If you wish for a child you must kill a pig and a hen." In the morning he got up, and as he very much desired a child he killed seven pigs and seven hens. Again the man dreamed and the woman came to him in his dream and said, "There is evil in your jar; that is why you have no child. It is in the Tompok. The Nantu (spirit) of the Tompok would like to do you evil but I do not wish it for I am a Nantu, also the Nantu of your Sungkiel. There is also an evil spirit in your Narajang. When the year is finished you must always kill a pig for the Nantu of the Tompok." After a time the man's wife gave birth to a child, and at the end of the year he killed a pig and prayed to the jar, and this he did each year in order that the two Nantus should not be angry with him any more.

\section{The Path of the Ghosts.}

Told by Sirinan of K. Piasau, Tempassuk District.

NoтE.-The ghosts of the dead are supposed by the Dusun of the Tuaran and Tempassuk Districts to ascend Mount Kinabalu.

There is a small river to the "laut" of Kampong Koung named Koraput. There are large stones in the middle of it and the people say the ghosts stop there on their way to Kinabalu. If the ghost of an old man is passing the sound of his walking-stick is heard tapping on the stones, if of a young bachelor the sound of his sendatang, ${ }^{2}$ if of a young unmarried woman the sound of the toreding, ${ }^{3}$ and if of a child the sound of weeping.

\section{The Bobog (Water Tortoise) and the Elephant.}

Legend told by Sirinan (Low-Country Dusun) of K. Piasau, Tempassuk District. NotE.-The Bobog has movable plates on the under side of his shell and with the help of these he is capable of shutting up the whole of his body.

The Bobog was walking one day near the river when he met the elephant. Said the elephant, "Bobog, what are you doing here?" "I am looking for food,"

1 Seawards.

2 A kind of native banjo.

3 A kind of wooden or bone Jew's harp. 
replied the tortoise. "Well," said the elephant, "I'm going to eat you." "Why?" said the tortoise. "Because I choose to," said the elephant. "Won't you have pity on me," said the tortoise, "I can't run away, as I can only walk slowly." "If you don't want me to eat you," said the elephant, "I will burn you." "But I am very much frightened of fire," said the tortoise, "if I see it I run away at once into the water. Well," continued the Bobog, "if I don't burn may I try and burn you afterwards?" And the elephant said that he might. So the elephant made a pile of wood as big as a sulap, ${ }^{1}$ building it on the sand near the river. "Bobog," said the elephant, " to-morrow morning early you must go into the pile of wood and I will burn you." "Very well," replied the tortoise, "I will go in to-morrow but as I am going in you must keep on calling to me and when I do not answer you any more you can set the pile alight." So the next morning the tortoise went into the heap of wood and for a long time, whenever the elephant called, he always received an answer, at last, however, the Bobog was silent. Then the elephant set fire all round the pile so that there should be no chance of the Bobog getting out. The fire burnt down and the elephant said, "Certainly the Bobog is dead." So off he went to the river to drink; but when he came back there was the Bobog walking about among the ashes of the fire, for he had buried himself in the damp sand of the river and shut up his shell, and thus had not been hurt. "You are very clever to have got out," said the elephant; "how does the fire feel, does it hurt or not?" "It is a little unpleasant," said the tortoise, "but what can one do if an elephant wishes to burn one." So the Bobog a'sked the elephant to help him to collect wood for his own burning, and for three or four days the elephant brought wood until he had made a heap far larger than that which had been used for burning the tortoise. Then the Bobog asked the elephant when he would go into the heap and the elephant answered that he would go in early the next morning. On the following day the elephant went into the pile and made a nice place for himself to lie down in. Then the Bobog called to him, "Elephant, are you comfortable, for I want to burn you ?" "Burn away," replied the elephant. So the Bobog set fire all round the pile and after a time the elephant called out, "The fire is very hot." "Well, I did not say anything about it," said the Bobog. Soon the elephant began to cry out that the fire was burning him. "Be quiet, can't you," said the Bobog, "I never cried out, and besides it's your own fault for you suggested burning me; I should never have thought of burning you." So the elephant was burnt to death, but the tortoise laughed and said, "Ah, elephant, you tried to burn an animal whose back is hard and whose face is hard, besides you cannot dig in the ground as I can." Then the Bobog made a toreding from a small bone of the elephant, and while he was walking along playing upon it he came to a large tree. Now there was a monkey in the tree and he, hearing the beautiful sound of the toreding, came down to see who was playing. " Bobog," said he, "where did you get your toreding?" " From the elephant's bones," replied the tortoise. "How did you get

1 Small hut. 
the elephant's bones?" said the monkey; "I should like to try your toreding." But for some time the Bobog did not let the monkey try the toreding; at last, however, he gave it to him and immediately the monkey snatched it and ran away with it up to the top of the tree; and the Bobog wept because his toreding had been stolen. After a time there came a small river crab and he asked the tortoise why he was crying. "Because the monkey has stolen my toreding," said the Bobog. "Where is he?" said the crab. "Up in that big tree there," replied the Bobog. "All right, don't worry," said the crab, "I will go up the tree after it." Now the monkey had its child with it and when the crab had got up into the tree the monkey's child saw it and called out, "Father," it said, "there is a crab up there close to you." "Oh, nonsense," said the father, "I expect it is only a knob of wood that you see." Then the crab pinched the monkey, the monkey dropped the toreding, and the crab dropped out of the tree. So the Bobog ran to get his toreding. and he thanked the crab, "For," said he, "without your help I should never have got it back again."

\section{The Lungun, the Bobog, and the Monkeys.}

\section{Told by Sirinan of K. Piasau, Tempassuk District.}

The Lungun (adjutant bird) was watching at its nest one day and fell asleep, and while it was sleeping, monkeys came and pulled out all its feathers. Then the Lungun cried, for he could no longer fly in search of food. After a time his mate came and brought him food and asked him how he had lost his feathers. The Lungun explained how the monkeys had come while he was asleep, and that when he awoke they were plucking out all his feathers. After two months the Lungun was able to fly, for his feathers had grown again. He thought and thought in what way he could revenge himself on the monkeys, but could find none. One day, however, when he was walking about, he met the Bobog, and he told him how the monkeys had stolen all his feathers and how he had not been able to fly for two months, and he asked the Bobog how he could take his revenge upon the monkeys. "I will help you," said the Bobog, " but you must go and hunt for a prahu first." "What is the use of that?" said the Lungun, "I am not clever at rowing." " Never mind," said the Bobog, "just get it, but it must be one with a good large hole in it, and I will get into the hole and stop it up." So the Bobog and the Lungun agreed to meet again in seven days and the Lungun set out to search for a worn-out prahu with a hole in it. He was not long in finding one, and at the end of seven days the Bobog and Lungun met at the place where the prahu was lying. Then the Bobog crept into the hole so that the water could not get in any more and the prahu floated away down stream with the Lungun standing on it. The monkeys saw the prahu and the Lungun on it and called to him asking him where he was going, and

1 Native boat. 
the Lungun replied that he was going for a sail. Then the monkeys asked the Lungun if they might come with him, and the Lungun replied, "Certainly," for he recognized among them many of the monkeys who had pulled out his feathers. So the monkeys, twenty in all, got into the boat, and when they were enjoying themselves, drifting in the prahu, another monkey called from a tree and he and his companions, twenty-one in number, also got into the prahu. Many other monkeys called to them, but the Lungun would not let any more come into the boat, for he said it would not hold more than forty-one. When the prahu had drifted out from the river into mid-ocean it was struck by waves, and the Lungun told the monkeys to tie their tails together, two and two, and to sit on opposite sides of the boat so that the prahu should not roll. Then the monkeys tied their tails together because they wished to stop the prahu rolling, but the forty-first monkey, who had no tail and only one hand, had no companion. When they were all tied up two and two the Lungun called, "Bobog, I'm going to fly off." "Very well," said the Bobog, "I'll swim off too." So the Lungun flew up from the prahu, and the Bobog coming out of the hole the prahu sank. Then the monkeys tried to swim but could not do so because their tails were tied together. So the fish eat them, and the only munkey who escaped was the forty-first, who had no companion tied to him. As for the Lungun he fiew away, saying, "Now you know what you get for pulling out my feathers."

How the Bajau came to the Tempassuk and the Dusun learnt the use OF BeESWAX.

Told by Serundai, Orang Tua of K. Kalisas, Tempassuk District.

There is a tree named kendilong which has a white sap like water, and this sap is very irritating to the skin. The kendilong is a home for bees, and if men wish to take the honey they cut steps in the tree up to the bees' nest.

Once there was a poor man, and every night he dreamed that if he found a. kendilong tree he would become rich. So he set out to look for one, and when it was near night he found a kendilong and slept the night there. Now, there were bees' nests in the tree. The next morning he went home and brought two companions back with him. Two men climbed the tree and one stopped below by the trunk. They took the bees' nests but did not know to whom to sell them. Now there was a Bajau who had come up the river in a prahu, for at this time there were no Bajau living in the country. This man met the Dusun who had got the bees' nests, and going home with them he saw four sacks of nests and bought them for a little cloth, saying that he did not know what they were. He said that he would try and sell the nests, and that he wished to become the Dusun's brother. So they swore brotherhood and sacrificed a hen, and the Bajau promised to give the Dusun his share if there were any profit from the nests; at the same time telling the Dusun to collect any more he might find. Then the Bajau sailed away and 
the Dusun searched hard for bees' nests. Now the Bajau had promised to return in three months' time, and when he came be brought a tankongl full of goods and he found the Dusun's house full of bees' nests. So the Dusun got much goods from the Bajau and became rich, and that is how the Dusun got to know about beeswax.

\section{The Legend of Nonok Kurgung.}

Told by Orang Tua Lengok, a Low-Country Dusun of K. Bengkahak, Tempassuk District.

Long ago when there were no people in this country of the Tempassuk, there were two people at Nonok Kurgung, a man and his wife. The woman became with child and gave birth to seven children at one time, both male and female, four were females and three were males. When these children were grown up they wished for husbands and wives, and asked their father and mother how they were to get them, as there were no other men in the country. Their father and mother said to them : "Wait, and if our dreams are good you will get your wish." When the woman was asleep Kenharingan came to her in her dreams and said, "I have come because I have pity on you that you cannot get wives or husbands for your children. Your children must marry one another as that was the reason I gave you seven children at one birth." In the morning the woman asked her husband if he had had any dreams, and he said, "No." Then he asked his wife if she had dreamed and she said that Kenharingan had come to her and told her that their children must marry one another. So they consulted together and ordered their children to marry, and after they had been married for some time all the women gave birth each to twenty children at a time, and these children in their turn intermarried. Now at this time the people had no kabuns, ${ }^{2}$ and they got their rice by cutting down bamboo stems; the rice coming out from the inside of the stem. There was a river with many nonok trees near the kampong and the children used to go and bathe there and lie under the trees. Every day they went to bathe there, and every day a child was lost. This went on until twenty children had been lost, and the fathers decided to try and find out what was happening to them. They searched the river and they searched the banks, but could find nothing, and there were no crocodiles in the river. After they had hunted in vain for three days they went home, and when they met together they decided they would run away from the place. So they collected all their goods to start. One night all was ready and the next morning they started out, taking with them their wives and children, their baggage and bamboos to give them padi. After they had journeyed for a day, one man and his family stopped behind to make a house, a second man stopped on the second day, and so on till there was nobody left to journey on. These families which stopped formed kampongs, and from their bamboos came all sorts of food-plants, vegetables, padi, and kaladi, ${ }^{3}$ and these they planted in their gardens. This is how this country became peopled with Dusun to as far away as Marudu.
1 Large boat.
2 Gardens.
3 Yams. 


\section{Tow ARDAKaN}

\section{From Orang Tua Lengok of K. Bengkahak.}

Towardakan is a son of Kenharingan; Kenharingan made all men equal. But Towardakan did not like this and brought it about that some men should be rich and some poor. For this he was expelled by Kenharingan. Towardakan does not like a good padi year for then all men are well off.

NoTE.-From inquiries made I cannot find that Towardakan is known at Tuaran.

\section{Why the Dusun of Kampong Tempassuk do not eat Snakes.}

Told by Gensiou, a Low-Country Dusun of Kampong Tempassuk.

There was once a man of Kampong Tempassuk in this country who wanted to marry. After he had been married for some time his wife gave birth, not to a child, but to a snake. When the snake had grown large the woman again gave birth; this time to a girl. Some time after the child had been born the man' and his wife went to bathe in the river and they ordered the snake to watch the child while they were bathing. So the snake guarded the child, wrapping it round with its body; and when the man and the woman came back from the river it unwound itself from the child and climbed up into the shelf where the padi stores are kept. The snake lived on the shelf for some time and when it had grown a little larger it left the house and travelled about for two days. At the end of the two days it came home and entering the house it went to its father and wound itself about him. It then climbed down to the ground and for the second time wound itself about him and descended to the floor. Then said its father, "Why does my snake son wind himself around me in this way?" so he followed the snake, which had gone off into the jungle, and after a time they came to a dead deer lying on the ground. Then said the man to himself, "Perhaps my snake has killed this deer and that is why he wanted me to follow him." So he went back to the house and the snake followed him, and when they arrived the father of the snake said to his companions, "There is a dead deer in the jungle which my snake has killed." So they went off into the jungle but the snake did not follow. When the men arrived at the place where the deer was they lifted it, and, carrying it home, made a feast. The snake however did not eat but remained on the padi shelf for three days. At the end of three days it again set out and was gone on its journey seven days. Then it returned and again it coiled itself round its father as if it wished him to follow and its father thought, "Perhaps my son the snake has got something again." So he followed the snake and when they got into the jungle there was a dead stag there as before. So the man carried the stag home but the snake stopped on the padi shelf. Then the man said to his companions, "I will put a collar and a bell round my snake's neck for somebody may kill it, as it is poisonous; but if they hear the 
bell they will know it is my son and will refrain." So he told all the men of the kampong that his son the snake was wearing a bell, saying, "If any of you see a snake with a bell round its neck do not kill it, for it is my child." Now at the end of seven days the snake set out again, and at length came to the country of Kinsiraban, and the men' of Kinsiraban killed the snake and eat it. After a long time the father of the snake heard news that his son had been killed, and set out for the country of Kinsiraban and, finding the snake's collar and bell there, he said, "It is my, son." So he made war upon the people of Kinsiraban and killed them. Then he went home and he commanded the people of Kampong Tempassuk not to eat snakes-in memory of his son. And though the Dusun of other kampongs eat snakes, we Dusun of Kampong Tempassuk do not do so to the present day, for the father of the snake was a man of our kampong.

\section{The Pwak (Horned Owl) and the Moon.}

Told by Sirinan of K. Piasau, Tempassuk District.

The moon is male and the Pwak is female.

Long ago when the sky was very low down, only a man's height from the ground, the moon and the Pwak fell in love and married. At that time there was a man whose wife was with child. This woman came down from the house and as the heat of the sun struck her on the stomach she became ill, for the sky was very low. Then the man was very angry because his wife was ill, and he made seven blow-pipe arrows. Early the next morning he took his blow-pipe with him and went to the place where the sun rises and waited. Now at that time there were seven suns. When they rose he shot six of them and left only one remaining; then he went home. At the time the man shot the suns the Pwak was sitting on the house-top in the sky combing her hair. The comb fell from the sky to the ground and the Pwak flew down to get it, but when she had found it she could no longer fly back to the sky ; for while she had been looking for the comb the sky had risen to its present place ; since, when the man had shot the six suns, the remaining sun, being frightened, ran away up into the air and took the sky with it. And so to the present day whenever the moon comes out the Pwak cries to it, but the moon says, "What can I do, for you are down there below, while I am up here in the sky."

\section{The Eclipse. The Story of the Tarob and the Moon.}

Told by Sirinan of K. Piasau, Tempassuk District.

The children of Kenharingan once pounded padi, and when they had pounded it the Tarobl came and ate it all up. Every time they pounded padi the Tarob came and ate it up, and at last the children of Kenharingan complained to their

1 The nantu or spirit who eats the moon. 
father and said, "Every time we pound padi the Tärob comes and eats it up." Then said Kenharingan, "If he comes again order him to eat the moon." So when the Tarob came again the children of Kenharingan said, "Don't you eat our rice ; go and eat the moon." And down to the present time the Tarob, when he is hungry, goes and swallows the moon, but the Dusun menghadji him and he puts it out of his mouth again, and goes and eats the rice which the Dusun place for him in their winnowing baskets.

\section{The Origin of the Blatek, the Ror and the Puru-Puru (Three Constellations).}

Told by Sirinan, a Low-Country Dusun of K. Piasau, Tempassuk District.

Long ago men planted only ubi, ${ }^{1}$ kaladi, ${ }^{2}$ and kachang, ${ }^{3}$ at that time there was no padi. When they had planted them they fenced them round and after a time they cleared away the weeds in the crop. At weeding time they found that wild pigs had been getting in and had eaten all their kaladi. "What use is it," said they, "our planting crops? The wild pigs only eat them." In the evening the men went home to their houses and when it was night they went to sleep. Now one man dreamed and in his dream an old man came to him and he said to the old man, "All my kaladi and ubi and kachang which I planted have been eaten by wild pigs." Said the old man, "You must make a blatek4 (spring trap) at the edge of your fence where the pigs enter." Then the man awoke, for it was near morning, and thinking over the dream he resolved to make a blatek near the edge of his garden. So he ate and when he had finished he went out to his kabun and started making a blatek. When he had finished it he set it and returned home and on the fourth day after he had set the trap he went back to his kabun to look if it had caught anything. When he got there he found a wild pig in the trap, but it had become decayed and was not fit to eat. He poked it with the end of his walking stick and found that its head was separate from the body and that the under jaw and teeth had fallen away from the head. The man went home and at night he went to sleep and dreamed that the same old man came to him and said, "What about your blatek, did it catch a wild pig?" "Yes," said the man, "I caught a pig but it had become rotten and I was not able to eat it." " Did you take a walking stick with you ?" said the old man, "and did you prod the wild pig's head with the stick?" "I did," said he. "Very well," said the old man, "Do not plant kaladi and kachang this year, plant padi instead." "But where shall I get padi from," said he, "for there is no padi in this kampong." " Well, search for it in other kampongs," said the old man, "if you only get two or three guntongs that will be enough. The marks where you thrust your stick into the pig's head shall be called the puru-puru. The lower jaw shall have its name of the ror, and the blatek also shall keep its

1 Potatoes, yams.

3 A kind of French bean.
2 Caladium, a species of arum.

4 Malay "bluntek." 
name and all these shall become stars." Then said the man, "I want instruction from you, for if I get padi how am I to plant it." Said the old man, "You must watch for the blatek, the ror, and the puru-puru to appear in the sky and when shortly after dark the puru-puru appears about a quarter way up in the sky, that is the time to plant padi. The puru-puru will come out first, the ror behind it and the blatek last of all." When the man woke up he found that the old man's words had come true and that the puru-puru, the blatek, and the ror had become stars, to the present day they follow this custom and the padi is planted according to the position of these stars as seen shortly after dark (about 7 o'clock).

\section{The Story of Langaon.}

Told by Sirinan, a Low-Country Dusun of Kampong Piasau.

Langaon had made a kabun sufficient in which to sow two mandores of padi and after a time it bore fruit. When the padi harvest came the men of the kampong went to reap in their kabuns and Langaon went also to reap in his, but when he had finished his reaping he found the produce of it was only two mandores, just what he had sown at first. "Why is this?" said Langaon. "Other men all have a good return from their sowing ; I alone have no padi." So he went to the old men of the kampong and told them about it. However, he decided to make another kabun and this time to sow three mandores. So he made his kabun, and sowed three mandores, and when his padi came up it was better than anyone else's in the kampong; when it began to fruit too it was finer than that in any other kabun. At length harvest time came and Langaon this time got three mandores of padi for his harvest while every other man had at least a full tankob Then he made up his mind to leave the village and search for better ground in which to plant padi. So he set out and after he had wandered for a long time in the jungle, at last he came to a small river and made himself a sulap there. Here he stopped and made borusats ${ }^{1}$ in the stream. The next morning he went to look at his traps, and found that he had got a large catch of fish. "Then," said he, "it would be good to stop here for there is no lack of fish ; only I have no salt and no padi, and how can I live without them?" So he set out with his fish to look for some place where he might sell them for salt or padi. After a time he came to a kampong and the people said to him, "Oh, Langaon, where are you going?" "I have run away from my kampong and am living near the river," said Langaon. "I have caught many fish but as I have neither salt nor padi, I have come here to sell them." Then they called him to come into the house and they gave him padi and salt and cooking pots and mats in exchange for his fish. So Langaon was much pleased and the people of the kampong asked him to come every day and bring them fish. When he got home he had sufficient to eat and vessels in which to cook, for hitherto he had used bamboo. ${ }^{2}$ So he decided to stop at the river, and make himself a large

1 A kind of fish trap.

${ }^{2}$ Large bamboos cut into lengths are used for cooking in. 
hut. The next morning there were again many fish in his traps and Langaon thought, "I shall be ashamed if I go every day to the kampong, so I will dry these fish in the sun, and to-morrow I will take them the dry fish and any fresh fish I get from the traps." On the following day, Langaon again went to the kampong, and the people of the kampong gave him parangs ${ }^{1}$ and spears and cloth in exchangefor his fish. Then Langaon said to himself, "I had better tell them I shall not come again at once, as the river has fallen since there has been no rain, and until rain comes again I shall have no fish." So he told them, but they said to him, "If you have no fish, come all the same." Langaon went home, and though he got many fish he did not go to the kampong for another week. At last, however, he started for the kampong with his fish, but when he got there, he said, "To-day I donot wish to sell my fish; I will divide them among you, but I will not take anything in return." So he divided the fish among them and each man got two. tempurongs ${ }^{2}$ full. "Why do you not ask a price for your fish," said the people of the kampong. "I am not without food," said Langaon, "I still have much left from what you gave me before, but if I have no food left and catch no fish, I will come and ask you for what I want." So it was agreed, and Langaon asked them. when was the time for making kabuns there, and they said, "As soon as this month is finished we begin to make them." When the month was finished, Langaon went, back to the kampong, bringing with him a little fish to give to the people, and again he asked them when they would start making kabuns. "Oh, any time wefeel inclined," said they, "to-morrow or the next day," and they asked him to come. and live in their kampong, but Langaon refused. So he went home and the next day he began to make a kabun, and when he had cut down all the trees, his kabun was large enough to sow two mandores of seed in. "Well," he thought, "I will rest a little till other people begin to burn" (the cut trees). After about twenty days he saw great quantities of smoke coming from near the kampong and going to his kabun, he tired it until not a single tree trunk was left. "This is. troublesome," thought he, "I have no seed to sow in my kabun." In the morning, he took his fish with him and went to the kampong to ask for seed, and when he was still far off, they started calling to him to bring his fish. So he divided his fish among them, everybody getting a tempurong full; and the people of the kampong asked him if he had sown his padi. "Not yet," said Langaon, "I came here to-day, to ask you to give me sorne seed." "How big is your kabun?" "About two or three mandores large," replied Langaon. So each man in the kampong gave him a mandore of seed, until there were none left who had not given. "Why do you give me so much?" said Langaon, "for my kabun is not a large one, only enough for two mandores. If each man were to give me one or two tempurongs. full I shall not finish it, but this you have given me is much more than I shall use; besides, how shall I get it home, for I shall only be able to carry two or three

1 Jungle knives.

${ }^{2}$ A half of a coconut shell used as a drinking or food vessel. 
mandores." "Never mind," said the men of the kampong, "whatever you do not want to sow you can leave here, and you can use it to eat." So when he went home he took only three mandores of seed with him, and the next day he started and sowed two mandores in his kabun. The padi sprouted and thrived, and Langaon said, "Ah, perhaps this year I shall have plenty of padi," and each day he went to his kabun, though there were no weeds in it. At last he said, "What use is it for me to go to the kabun for there are no weeds in it," and for six days he remained at home. On the seventh day he went back and found that Maragang monkeys had broken into his kabun and damaged his padi. Then Langaon wept, "Ah," said he, "all my padi has been destroyed." So he tried to raise the stems which the monkeys had beaten down, and he resolved to move his house to the kabun, so that he might guard what remained of the crop. He stayed there at the kabun until his padi had recovered, and when it was ripe, he said to himself, "I must make my binolet." Then he went into the jungle to get wood for the binolet, and slept a night there, but when he returned home he found not a single grain of padi left in his kabun, all the ears of grain had been taken and only the straw left standing, and there were tracks of many monkeys everywhere. "Ah," said Langaon, "I will run away from here, for first of all the monkeys damaged my crop, and now when it is ripe they have come again and eaten it all." So he set out again, and after he had wandered in the jungle for a long time, at last he made another sulap, but this time there was no river near, and he had to live on whatever he could find in the jungle. He had brought away with him the one mandore of padi seed which he had not planted in his former kabun, and here he again made a kabun and sowed the seed in it. This time he made his kabun round his house so that he might keep a guard on his crop, and when the padi came up it was very good. There he lived until his padi was in the ear. One day he went to fetch water from the river and on coming back he saw a great many Maragang monkeys near his kabun; though they had not yet entered it and eaten his padi. Then he dropped his water vessel and went to drive away the Maragangs, but the monkeys attacked him, and Langaon ran away, for he had first come from the river, and had neither parang nor spear with him. When he got to his sulap he snatched up his spear and wounded one of the monkeys and they all ran off, except the largest of them, which still fought with him. Then Langaon retreated from the monkey backwards, until without noticing it, he became entrapped between four large tree stumps which stood in the kabun; and there both Langaon and the monkey stopped fighting while after some time the monkey suddenly became transformed into a beautiful woman. Langaon seeing this, came out from the tree stumps and spoke to her. "Where do you come from?" said he. "My mother ordered me to come here," replied the woman. "When you made a kabun before, I came there also, but you did not guard your padi. The padi which you said monkeys ate was reaped and I also was among the reapers." "Where did you put the padi?" said Langaon. "In my house," said the woman, "and the people of my

1 Proboscis monkeys. $\quad 2$ Wooden store vessel for ears of padi. 
kampong reaped with me." "Well," said Langaon, "I have no food, for this padi is not yet ripe." "You had better come home to my house," said the woman. So Langaon followed the woman home, and found that her house was in the jungle, and not far from his kabun. "I am alone here," said she, "for my father and mother and my companions are in my kampong which is a long way off. $\mathrm{My}$ father has much pity for you because you have no wife, and I also. All this padi in my house is yours, for when you made the kabun in your village, it was I who stole your padi, and when you made a kabun by the river, I went there also.". So Langaon stopped there, and the woman told him how she was really a Maragang monkey, but had become a woman. Then she became his wife, and Langaon said, "I will search for some kampong near, for it is evil for us to be all alone here." "Oh," said the woman, "if you want a kampong, there is one not far off," and she pointed out a kampong to him which he had not noticed before; but his wife besought him not to go there, and so he remained with her. At last, when they had a child, Langaon said, "I should like to go to the kampong, if I start to-day I shall return to-day also, for it is not far away." His wife said, "Do not go, for I shall be very much frightened, while you are away there." But Langaon did not pay attention to his wife's words, and after a while she said to him, "Well, if you go do not sleep the night there, for I shall be all alone here with the child." So Langaon started off, and when he got to the kampong he found a great feast going on, and joining in it he became drunk and forgot about going home. For seven days he stopped there eating and drinking, and on the sixth night he fell in love with a woman of the kampong. However, on the seventh day he started home. and when he came to his house, his wife was very angry and would not speak to him. "Why are you angry?" said he. "Why should I not be angry," said his wife, "for you have been unfaithful with another woman, for though you were far off, I know it, and you have a mark on you by which I can tell." But Langaon denied it. "If," said his wife, "you deny it, I will take from you the mark by which I know that you have been unfaithful." “You may take it," said Langaon. "Well," said she, "I will show you, for I am the God of your kampong (Kenharingan Tumanah)," and taking a looking-glass she showed him the appearance of the other woman and himself in the glass. Then said Langaon, "It is true." "I will leave you," said his wife, "and take the child with me, for you have now a wife in the kampong." But Langaon asked for pardon, saying he would pay what was according to custom, as a recompense. But still his wife refused to stop with him; so when it was near night he bound her hands and feet to his, for he was frightened that she would run away. So they slept, but when Langaon awoke in the morning, the ropes were opened, and his wife and child had gone. Then Langaon wept, for he did not know the kampong in which his wife lived. On the second day he stopped weeping and started out to look for his wife, "For," said he, "wherever I find a kampong there will I search." So he wandered in the jungle and one day he met a herd of deer which attacked him. Then Langaon ran away and crept into a hole in the ground and hid, and the deer could not catch him. 
The next morning he came out of the hole and started again, but he had not gone far before he met a herd of wild pigs and these also attacked him, and as before he ran away until, coming to the same hole, he again got into it to hide. There he slept and dreamed, and in his dream a man came to him and said, "Langaon, you are a coward to run from the deer and wild pig, for if I were looking for my wife I would fight them." "How can I fight them," said Langaon, " for I am all alone and they are many?" "If you journey again to-morrow and are brave," said the man, "you will get your wife back, for she will ride a rhinoceros." " Formerly I was not afraid even of the rhinoceros," said Langaon, "but I found that I was afraid of these stags and wild pig." "If you are afraid," said the man, "you will not get your wife back." "How shall I know the animal she is riding," said Langaon, "for the other animals had no one riding them?" "You will know the one," said the man, "because it will have bells on it; that is the one you must hunt, but do not let it go or you will lose your wife." In the morning Langaon awoke, and set off early in search of his wife, and, after a time, he came upon a herd of rhinoceros and among them he saw a large one which had bells hanging round its neck. So he waited for the rhinoceros with the bells to attack him, and did not run away, and when. he caught hold of it by the bells round its neck all the rest of the herd vanished. The one he had caught also tried to escape, but Langaon struggled with it for three days, until he stumbled and fell close to his own house, and in falling he let go the bells. The rhinoceros disappeared and Langaon sat down to think outside his house. After a time he heard a child begin to weep inside and he went in to see who was there, and opening his door found that his wife and child had returned.

NoTE on Kenharingan Tumanah. The form of oath generally in use among the Dusun runs as follows: "I swear by Kenharingan above and by Inthe-Earth (dalam Tanah), i.e., by Kenharingan Tumanah, the God of my kampong, that I will speak the truth, if I do not do so, may a crocodile eat me, may a tree fall on me in the jungle, etc., etc.

\section{The Legend of Ligat Liou.}

\section{Told by Sirinan, a Dusun of K. Piasau.}

There was once a man named Tamburan. One day he took his parang and spear and his bareit ${ }^{1}$ and went off to look for vegetables in the jungle, for he was poor and had no food. He searched and searched but could find nothing ; at last, however, he came to an old kabun and seeing a sulap near it he went to look if there were any people in it, for he thought that the kabun was still being used as there were many gourds there. Putting down his bareit and spear he climbed up into the hut, and there he saw a woman lying down. Now she was

${ }^{1}$ Small carrying basket. 
unable to sit up because her head was very large while her neck was only as thick as my little finger. The woman, whose name was Ligat Liou, ${ }^{1}$ spoke to him and said, "Tamburan, why have you come here?" "I have come looking for vegetables," answered Tamburan, "for I have nothing to eat and nothing with which I can buy padi." "If you are hungry," said Ligat Liou, "there is some rice ready cooked there on the saleian, ${ }^{2}$ which you can eat and you will find fish there too." "How does she manage to pound her rice," thought Tamburan, "for she cannot even sit up." Then he said, "I do not like to eat alone." "I have eaten just now," said Ligat Liou, " do not be ashamed to eat." So Tamburan took the rice and ate and when he had finished Ligat Liou asked him to come and search for lice in her hair; so he went to search, but instead of lice he found in her hair scorpions and little snakes and centipedes and all other sorts of poisonous animals. Then he killed them all till there were none left and Ligat Liou thanked him, saying that none of the women who came there would search for lice in her hair. "But now," said she, "I shall be able to stand up, for my head is light since I am free of all these lice." So she stood up and said to Tamburan, "Take seven gourds from this kabun." So Tamburan took the gourds and brought them into the sulap. Then said Ligat Liou, "Take this first gourd as soon as you get home and cut it in two; the second one cut open when you get into your room; the third you must open in your store room; the fourth on the padi shelf, the fifth on the verandah, the sixth below the steps, and the seventh below the house." Then Tamburan went home and on reaching his house be did as Ligat Liou had instructed him, for his children were crying for food. When he cut open the first gourd he found rice and all other kinds of food ready cooked in it, together with plates and drinking cups. So they ate and when they had finished he cut open the second gourd in his sleeping room and in it were mats for sleeping on and all the furnishings for a bedroom. The third gourd he opened in his store room and from it came gongs of all kinds, tawags ${ }^{3}$ and chenangs ${ }^{4}$ and tenukols ${ }^{5}$ and other goods besides. The fourth gourd he opened on the padi shelf and from it came great quantities of padi. The fifth he opened on the verandah and in it were many hens. The sixth he opened below the steps and out of it came great numbers of pigs. The seventh held many kerbaws; this also he cut open, as he had been ordered, within the fence below the house. Now when the gourds were cut open there was a man in the house named Sikinding, who lived in another room. This man was also poor and he came to Tamburan and said, "Brother (Pori San), where did you get all these goods from?" Said Tamburan, "I was astonished at getting them myself, for I dreamed I was rich and when I woke up I found it was true." "Ah," said Sikinding, "I always dream at night but I have never become rich from it," for he did not believe

1 Little neck.

2 Shelf above the fire.

3 Two kinds of gongs. The tawag-tawag is a thick and deep gong with a protruding: boss.

4 The chenang is a shallow gong in which the boss is almost on a level with the surface.

5 The tenukol, a large and rather cheap kind of gong. 
Tamburan's words. "It is true," said Tamburan, " for you know well that yesterday I was as poor as you and went with the rest of the men to look for vegetables in the jungle." But Sikinding still did not believe him and said, "Perhaps you got them from someone." "I spoke truth," said Tamburan, " and this is my dream, I dreamed that I came to an old kabun and that I went into a hut there, and that I got the goods from the person who lived in the hut." "Well," said Sikinding, "I will try and find this kabun and the person you dreamed of." "Just as you like," said Tamburan, " for as I told you I only dreamed of the place." "I shall start to-morrow, said Sikinding. "Well, I am not ordering you," replied Tamburan, " you are going to please yourself." So the next day Sikinding set out to look for the kabun, but having searched for two days and not finding it he went back and told Tamburan that he thought he was a liar, saying that he had searched for the kabun for two days and not found it. "For," said he, "I think you really went to the kabun and not that you dreamed about it." But Tamburan again replied that it had been a dream. "Ah," said Sikinding, "I don't believe you, how many times have men dreamed in this kampong and never yet got rich from it." "Well, try once more to find the place," said Tamburan, " and perhaps you will succeed." So on the next day Sikinding set out again and not finding it returned after he had searched for four days. Thought Sikinding, "Perhaps Tamburan is trying to kill me by sending me into the jungle, this time I will take my spear and parang when I ask him, and if he will not tell me, I will kill him." Then Sikinding went to Tamburan's door and said, "I still do not believe your story though I have hunted for the kabun for four days. If you do not tell me the truth this time I will kill you, for if my luck had been bad in the jungle I should have died there." But Tamburan still declared it was a dream, and Sikinding getting angry snatched the sheath from his spear and Tamburan ran away. Then Tamburan cried out that he would tell the truth, for he was afraid that Sikinding would kill him; so Sikinding stopped chasing him and Tamburan told him how he had gone to the kabun and how he had marked the trees with his parang, so as to know the way back. "Well," said Sikinding, "I will not kill you if you will show me the way." "But, perhaps," said Tamburan, " you will not be brave enough to hunt for the lice in her hair." "Oh," said Sikinding, "however brave you are, I am braver." "Well, when you come to the kabun," said Tamburan, "if anybody asks you to search for lice, you must not be afraid, for many men have been there, but I only was brave enough." "Oh, I shall not be afraid," said Sikinding. So the next day he set out and followed the marks which Tamburan had made on the trees, and at length he came to the kabun. When he was still some way from the hut he began calling out to know if there was anyone inside; but no answer came. So when he had come to the hut he put down his bareit, and going in saw Ligat Liou there and she said to him, "What do you come for ?" "Oh," said Sikinding, "I have no padi and I have come to look for vegetables; I am very hungry; where is your rice?" "How should I have rice?" said Ligat Liou, " for I cannot get up to pound it." "Oh ! that's not true," said Sikinding, "for how can you live if you have no rice?" "Well, it is true," said Ligat Liou, "for as you 
see yourself I cannot get up." So Sikinding went to get her rice from the shelf over the fireplace, but on taking down the plate he found nothing but earth in it. "Ah," he said, "you people in this kampong are no good ; you eat earth." " I told you I had no rice," said Ligat Liou, " but you can take a gourd from the kabun." Then Sikinding went and took a gourd, and going up again into the hut he asked Ligat Liou how he was to eat it. "You must cut it open," said she, " and eat what is inside it." So he cut it open and found a little rice and one fish in it, and from this he made his meal. When he had finished eating the rice and fish he said to Ligat Liou, "That is not enough; I'll go and take another gourd and that will be sufficient." "You can take another," said she, "but only one." So he brought another gourd, and cutting it open found inside it only rice in the husk and uncooked fish. "I've not had enough to eat," said he, "where can I get it from ?" "You can cook the food here," said Ligat Liou. "No, I won't do that," said Sikinding, "I will take it home and cook it; but I want seven gourds to take home with me." "I will give them to you," said Ligat Liou, "but first come and look for lice in my hair." So Sikinding went to look for lice but when he saw the scorpions and snakes and other poisonous things he cried out and was not brave enough to kill them and he let Ligat Liou's head fall first to one side and then to the other. "Well," said Ligat Liou, " if you are afraid to kill my lice you had better go home. But take one gourd with you; you may take a large one, but do not take more than one." Then Sikinding took the gourd and Ligat Liou said to him, "When you get home and wish to open this gourd, get into your tankob ${ }^{1}$ and make your wife and children get into it as well ; but shut up the top of the tankob well so that nothing can get out." So Sikinding ran home and calling his wife and children, they all got into the tankob with the exception of one small child, for whom there was no room. Then Sikinding opened the gourd and from it came out snakes and scorpions, which bit Sikinding and his wife and children until they died. The only person who remained alive was the small child for whom there had been no room in the tankob.

NoTE.-A variant of this tale is known among the Dusun of Tuaran. Tamburan is, however, replaced as hero by a man named Rahah Bujang, and there are other points of difference.

\section{The Lazy Woman and Her Bayong.}

Dusun story told by the Orang Tua of K. Tarantidan, Tempassuk District.

Long ago there was a very lazy woman; she would not work and as for bathing she was so lazy that she only washed herself once in ten days. One day she went to the bathing place and a nipah palm called to her from across the river. The palm-tree kept on calling her but she was too lazy to answer or to cross the river to see what it wanted. At last the nipah said, "Why are you so lazy that you will

${ }^{1}$ Large store vessel for padi, made of tree bark. 
not cross the river? There is a prahu there on your side of the water and you can row across and take my shoot." So the woman went very slowly and got the prahu and going very lazily across the river in it, she took the shoot from the palm. Then said the nipah, "I called you because you are so lazy. You must take this shoot and dry it a little in the sun and make a bayong ${ }^{1}$ from it." Now the lazy woman nearly wept when she heard that she was to make a bayong; however, she took the sprout home and made a bayong from it. When this was finished it spoke to the woman and said, "You must take me along the path where people are going to Tamu ${ }^{2}$ and put me down near the side of the road where everybody passes, then you can go home." So the woman took the bayong and left it near the road where people were going to Tamu. Many people passed there, but no one noticed the bayong until a rich man came along and, seeing it, said, "I will take this bayong to Tamu as it will do to put anything I buy there into, and if the owner is at Tamu I can give it back to him." Presently the rich man came to the Tamu and he asked everyone there if they had lost a bayong, but nobody acknowledged it. "Well, then," said the rich man, "it is my gain and I will put what I have bought into it and take it home; but if anyone claims it they can come to my house and get it." So the rich man put all his goods : sireh, lime, cakes, fish, rice, and bananas into the bayong until it was full, and while the man was talking to some of his friends, the bayong started off at its own accord to go home to the lazy woman's house. When it was still some little way off from the house it began calling to the lazy woman, "Come here, come here and help me for I can't stand the weight." Then the woman went to the bayong, though she was nearly weeping at having to go and fetch it home, but when she saw that it was full of all sorts of good things she said, "This is a splendid bayong, but perhaps it will want some payment. At any rate if it is always like this I shall get an easy living by just leaving the bayong on the road to Tamu." So on Tamu days the woman always placed the bayong near the side of the path and it always came home full; but it never met any of the men who had found it before until it had cheated six men. Now at the seventh Tamu the men who had filled the bayong at the six previous Tamus and had thus lost their property, happened to be going to Tamu all together and when they saw the bayong left near the road they all recognized it as the one which had cheated them. So the six of them collected buffalo dung and filled the bayong to the top, "For," said they, " this bayong is a proper rascal." Then the bayong being full started off straight for home and did not go to the Tamu. When the lazy woman saw it coming she rushed to help it home, but when she found it was full of buffalo dung she began to cry, "For," said she, "if the bayong does not bring me food, surely I shall die." As for the bayong it would never bring food from the Tamu again.

1 A large basket for carrying, made from the nipah shoot; it has no cover.

2 Market. 


\section{KADUAN.}

\section{Dusun legend told by Limbong Orang Tua of K. Tambahilik, Tempassuk District.}

Once there was a man named Kaduan who had a wife and seven daughters. His wife and daughters were ill with balang, ${ }^{1}$ and they were all so hungry that in a short time they would have been reduced to eating the ashes from the fire. Then Kaduan said to his daughters, "It is no good going on like this, I will search for husbands for you." Now his daughters were wearing "dampon "2 for clothes. They said to him, "Father, why do you want to search for husbands for us. It is not fitting ; for we are women, besides we are almost dying with disease and we are so poor that we have nothing to eat ; our house, too, is worn out and the roof beam has fallen down at one end till it touches the ground?" However, the next morning Kaduan set out, and at length came to a pengkalan ${ }^{3}$ on the river, where the sand of the river was composed of beads of gold; there were also Kalian trees there whose fruits were gongs and bells and the gongs and bells were sounding in the wind. So Kaduan bathed and crossed the river to the house of a man named Gerlunghan. The place below the house was full of fowls, for Gerlunghan was very rich. Then Kaduan climbed the steps of the house and Gerlunghan met him and asked where he was going. "I am looking for husbands for my daughters," said Kaduan; "for, though it is not very fitting that I should seek for them, still your people are the same as mine both in appearance and in wealth. I have been in the jungle for seven months, and my clothes are worn out, but when I first left my kampong they were all covered with gold like those which you are wearing." "How hungry you must be," said Gerlunghan, "after being in the jungle seven months. I will cook food for you." Said Kaduan, "If you cook for me do not cook as for three or four men, but for five or six, for I am very hungry indeed." So Gerlunghan had rice cooked in huge pans and with the rice he gave Kaduan three fowls. When Kaduan had finished the rice a man in the next house remarked, " How big is this man's stomach, it must be like a basong." Then Kaduan turning round looked at the trenchers from which he had eaten and they had again become piled up with fish and rice, but no man had put the food upon them, it had appeared of itself. Perhaps it is true that this man is rich in his own kampong, thought Gerlunghan, for he had finished the food, but when he turns round to look at the plates from which he has eaten they become full once more. Then Kaduan ate again, and he said to Gerlunghan, " Inquire of your sons whether they will marry my daughters, for I am tired of searching for husbands for them since I can find none like them for beauty in this country and none who can approach me in respect of my wealth." So Gerlunghan inquired among his seven sons and the eldest said, "Father, I do not wish to go for I

1 A very bad skin disease.

${ }^{2}$ Cloth made of tree bark.

3 Bathing-place. 
have never seen this man Kaduan before and I do not know what sort of a man he is, whether good or bad"; but his seventh son said, "Whatever my father orders I will follow." "Perhaps you think he is poor," said Gerlunghan, "but his clothes are worn out because he has been so long in the jungle." So the eldest son refused to go, but at last seeing that the others were willing, he said, "Well, I do not wish to be left behind so I will go too." "If it is settled," said Kaduan, " I will go home for seven days, at the end of that time I will come back and marry your sons for it is not right for my daughters to come here, for it was I who sought husbands for them." So Kaduan went home and when he got to his house he found his children eating the ashes from the fire. Said he to them, "I have found husbands for you, the children of Gerlunghan, and in seven days I go to marry them." "You will only make us ashamed," said his daughters, "for we are all ill with balang and we have nothing to eat." "Why do you not follow my orders," said Kaduan, "as Gerlunghan's children followed his?" When the time was up Kaduan started off again in his clothes made of dampon. ${ }^{3}$ At last he came to Gerlunghan's, and before he climbed the steps he called to Gerlunghan and said, "I have come here in my old clothes for everyone knows how wealthy I am, and I was afraid of being robbed and killed by the way for the sake of my golden clothes; for the clothes I wear are always of gold ; my house is seven doors long, and the windows in the roof are seven also, my sleeping mats, too, are more than a span high from the floor. I have seven jars for my arrack, and when I eat I have five trays of rice before me and I finish them at a meal." Then somebody said, "A man who eats like that should have a big stomach"; but they looked at his stomach and saw it was like that of a man who eats but seldom, and they were all astonished. "Well," said Kaduan, " my feast is ready at my house, and you, Gerlunghan, must follow me with your sons, but though I have killed buffaloes and cooked rice I have not a single fowl." The next day they set out for Kaduan's house, Kaduan, Gerlunghan, and his seven sons, and Kaduan walked as though he were flying, so that he had always to stop and wait for Gerlunghan and his sons. Thus Kaduan arrived first at the house and told his wife and daughters to run out of the house and hide. So they rolled away into the jungle, for they could not walk because of their balang. When Gerlunghan and his sons carne to the place they looked about expecting to find a beautiful house, but all they could see was a small tumble-down house with a path leading to it which looked like the track of a single man-Kaduan himself had also run off into the jungle. After a time Kaduan returned saying, "Gerlunghan, you can kill me." So he asked first one and then another to kill him but no one was willing. Then Gerlunghan's youngest son said to his father, "I will strike him," and snatching out his parang he wounded Kaduan on the arm, cutting him to the bone, and much blood came from the wound. Now as Gerlunghan's son yelled and chased Kaduan near the house, the blood which fell from Kaduan's wound turned into buffaloes and cattle and fowls. The house also became new and beautiful, and the sound of gong

1 Tree bark. 
beating was heard from within. Then Gerlunghan marvelled and said, "This man is even more wealthy than I." But Kaduan went to look for his children in the place where he had hidden them and he found them well and beautiful and dressed in magnificent clothes, and Kaduan's own clothes also had turned to gold. So Kaduan killed seven buffaloes and seven cattle and brought out seven jars of tapai, ${ }^{1}$ and made a great feast for Gerlunghan, and when the eating and drinking were over Gerlunghan returned home, but his sons remained with Kaduan.

\section{The Mosquitos' Kampong.}

\section{Bajau legend told by Si Ungin of K. Kotabelud.}

A long time ago a man was once hunting in the jungle and when it was near nightfall he wished to return home, but having wandered from the path he was unable to find it. While he was still searching for the way he came upon a large house near a kampong. So he went into it and meeting there an old man he told him how he was lost and asked for leave to sleep there. "Yes," said the old man, "you can sleep here, for you cannot find your way home to-night, as it is already dark." After a time, other people, men, women, and children, came to the house, and the old man told them about the stranger, saying, "Let us give him a bed for the night." Then they brought him food, but instead of water they gave him blood, and for rice they gave him maggots. "Perhaps I am among evil spirits," thought the stranger; so he ate a little of what they had given him. "Why do you not eat?" said the old man; and the stranger replied that he was troubled about having lost his way home. "If you cannot find your way home," said his host, " to-morrow I will send one of my men with you to show you the path." Then the women of the house said that they would find him a mat to sleep on ; but when they brought it, it was only a banana leaf. So the stranger and the people of the house lay down, but the former could not sleep owing to the great number of mosquitos. Then as he heard none of the other men in the house striking at the mosquitos, he thought, "Perhaps this is the mosquitos' kampong," and so he also did not try to kill them but brushed them gently from his body; and when he had done this once they no longer returned to disturb him. However, he did not sleep for he was afraid. When morning came the old man looked at the stranger's mat and seeing no dead mosquitos there he said to him, "Well, my son, you wish to go home and you shall have someone to show you the way. This, my younger brother, shall go with you, and you shall become brothers to one another, only do not bring him to your house but let him go when you find your path; for we are all mosquitos, and that was man's blood you drank last night. You must take this bombong. ${ }^{2}$ with you, and when you get home call your father and mother and brothers and sisters to see what it contains, but do not open it before you get to

1 A kind of intoxicating drink made from rice.

2 Bamboo box. 
your house." So the stranger went home, the old man's younger brother accompanying till he found the path. When he got to his house he told his relations what had happened to him and how the old man had given him the bamboo box and had ordered him to open it in the presence of his father and mother; speaking thus, he opened the box and from it he brought out gold ornaments, rings and bracelets, and fine clothes. Now when the stranger's elder brother saw the gold and the fine clothes he said, "I also will go to the kampong and tell the people that I am your brother." So he started and after a time he too lost his way in the jungle. When it was near night he came to the kampong of the mosquitos and asked the old man to let him sleep there; and he told the old man how his brother had lost his way in the jungle before and how he had come upon a house when he. was lost and that the people of the house had given him gold and fine clothing. "But," said he, "I do not know if this is the house." Then the old man ordered them to bring food for the elder brother, and for water they brought him blood, and for rice, maggots. "What sort of food is this you give me?" said the elder brother. "Blood and maggots! I cannot eat it." When the time for sleep came they brought him a banana leaf instead of a mat; and he said again, "What is this you have brought me? This is a house not the jungle. I want to sleep on a mat, not on a banana leaf." Said the old man, " These are our mats ; sleep on it if you will, but if not what can I do, only do not say I have no respect for you." So the elder brother slept, but before long he awoke and found that he was being bitten by swarms of mosquitos. Then he started slapping away at them right and left, and in the morning when he wished to go home there was no blood left in his body. In the morning the old man told him that he must return and gave him a bamboo, telling him not to open it till he came to his house. "But," said the elder brother, "how can I go home for I do not know the way!" The old man replied that he must find the way for himself. So setting out he at length came upon the path and reached home safely. Then he called together all his relations and friends and said, "I also have got a bamboo and I think there must be gold and fine clothes in it too." But his younger brother asked him, "Did a man guide you home?" and the elder brother said "No." So the elder brother opened the box and from it came out scorpions and centipedes and other poisonous animals and stung him to death, but no one else in the house was touched by them. Thus the elder brother fell down and died; and the younger said, "My brother must have offended the people of the kampong."

Mosquitos do not make their buzzing unless they are near men's ears and then they say, "If these were not your ears I would swallow you." (Si Ungin.) [Bajau version.]

\section{Dusun Version.}

The mosquito says, "If these were not your horns I would swallow you."

(Sirinan.) 


\section{The Belukun (the Scaly Anteater).}

Dusun legend told by Sirinan of K. Piasau, Tempassuk District.

A long time ago there was a man named Andarian who went into the jungle to look for vegetables. He carried his basongl on his shoulders and as he was searching for vegetables he said aloud, "This is why I have to search for vegetables to eat ; because I have nothing with which I can buy padi." Then a Belukun who happened to be near said, " $\mathrm{Oh}$, Andarian, what is your work in the jungle here?" Said the man, " $\mathrm{My}$ children are crying for food, and the vegetables I am gathering in the jungle are all I can find to give them." " Come here," said the Belukun. So Andarian went to the place where the Belukun was sitting in a hole in a tree, and the Belukun again asked him why he was looking for vegetables. Andarian replied again, "Because I have nothing with which I can buy food." "Very well," said the Belukun, "you can throw away your vegetables." "Why does he want me to throw them away," thought Andarian, "I don't see any padi in his place in the tree." However, he took his basong and poured the vegetables out of it. "Now," said the Belukun, "place your basong beneath my anus and strike me gently on the back, only do not strike hard." So Andarian struck the Belukun gently on his hinder parts and cloth and cooked rice and fish ready boiled came out from the Belukun until Andarian's basong was full. Then the Belukun told him to stop striking, "For," said he, "your basong is full. You had better eat," said the Belukun, "for I know that you are hungry; and when all the rice in the basong is finished you can come here again." So Andarian sat down and ate, and when he had finished he went home. Then he called together all his people and they also ate their fill, but while they were eating a dog came and a grain of rice fell upon its head. Now this dog belonged to a woman named Lintago, and when it went home she saw the grain of rice sticking on its head. She took the grain from the dog's hair, and wondered from where anyone had got rice, for the kampong, was starving; she put it into a large jar full of water. Then she called all her people to "eat rice," and they drank the water in the jar till it was all finished. But one of Lintago's little children swallowed the grain of rice, and Lintago was very angry and asked who had eaten it, "For," said she, "I wished to divide it so that everyone might have a little." So she asked all the people of the house about it until she was told that the little child had eaten it, and, being angry, she beat the child. "I will find out where this rice comes from," said Lintago, and she started off to inquire in the kampong. At last she came to Andarian's house and she asked him where he had got rice from. "I have no rice," said Andarian. But Lintago asked him again and again if he had not got rice, but Andarian always answered "No." "Very well," said Lintago, "if you will not tell me to-day I will kill you." Then Andarian became frightened and said, "It is true the rice was mine, but it is finished."

1 A kind of large basket. 
"Where did you get it from?" asked the woman, and Andarian told her how he had got the rice from the Belukun. So Lintago ran home and got a basong as big as a house, and off she went into the jungle, saying that she would not stop hitting the Belukun until he had filled her basket. When she got to the place where Andarian had been she started calling out that she was gathering vegetables as she had nothing with which she could buy food. At last the Belukun called to her, "Oh, Lintago." "Where are you ?" said she. "Here I am," said the Belukun, and he came out of his hole in the tree and asked what she was doing. "Oh," said Lintago, "I heard how Andarian got rice here, and I also am too poor to buy it. Will you give me some?" "I have not much," said the Belukun, " but there is a little," and he told her to place her basong as Andarian had done ; "But," said he, "when you strike me do not hit me hard." "If you do not fill my basket," said Lintago, "I will not. stop hitting you," and she began to beat him hard; but there came from him only wood potatoes ${ }^{1}$ and kaladi, and when the basong was nearly full, about a gantang measure of uncooked rice and also a little raw fish. When the basong was full, Lintago went off with it as fast as she could to get home. So they eat the kaladi and ubi kayu in her house, and Lintago said, "When these are finished I will go and get some more, for there are plenty there." Now Andarian heard about all this and he thought, "Perhaps Lintago will kill the Belukun ; I will go and see to-morrow." The next day Andarian started off, carrying only a small bareit, and going straight towards the Belukun's house he called to him from a distance. After a long time the Belukun answered him, for he was very ill from Lintago's treatment of the day before. "Why did you not answer at first?" asked Andarian. " I am very ill," replied the Belukun, "because Lintago struck me so hard yesterday. Why did you tell her about ne ?" "I did not want to tell her," said Andarian, " but she kept on asking me from where I had got rice, and at last she threatened to kill me, and then, being afraid, I told her." "Why did you not bring a basong to-day ?" said the Belukun. "Because I have not yet finished what you gave me before," said Andarian. "Then," said the Belukun, "I am your brother and though you have not brought a basong still I will give you something. Take this little sumpitan." "I only came to see if you were ill," said Andarian, " and I do not want a gift." But the Belukun gave him the sumpitan saying, "Whatever you aim at with this you will hit; if your house is old, blow through this sumpitan and it will become new, and if you wish for buffaloes or pigs or hens blow into the sumpitan and they will appear; only do not show it to anyone. For I am not really a Belukun but the god of your kampong (Kenharingan Tumanah) and I have a great liking for you." So Andarian promised he would not show the sumpitan to anyone, and went home, and when he got to his house he hid it. The next morning Lintago went off again to look for the Belukun, taking her basong with her as before. She was not long in getting to the place, but when still a little way off she started calling, "Belukun, Belukun." But the Belukun would not answer, and she could not find

1 Ubi kayu=yams.

${ }^{2}$ Blow-pipe. 
the tree he lived in. Then she began shouting that if he did not answer her she would eat him when she caught him. So the Belukun thinking that if he did not answer he would be killed, came out and Lintago immediately put her basket below him and struck him with her hand, but only a few potatoes and kaladi came from him. Then she took a small stick and started beating him, but nothing more came out. At last she got in a rage and began to beat him very hard, but still without result. "Why, what's the matter with the beast?" said she, and looking up the Belukun's anus she saw his heart beating inside his body. "Oh," said she, "here is a kaladi which has not yet come out," and plunging her hand into the Belukun's body she seized his heart. Then the Belukun, being in great pain, began to climb up the tree to get away, and his anus having closed on Lintago's wrist she was drawn up the tree after him. "Stop, stop," yelled Lintago, "I have let go of the kaladi inside you." But the Belukun climbed to the very top of the tree, and then releasing Lintago's hand she fell to the ground and was killed. "That's a bad woman," said the Belukun; "that was my heart she had caught hold of, not a potato."

\section{The Kerbau and the Pisang (Banana Tree).}

Illanun legend told by Orang Kaya Hadji Arsat of Fort Alfred, Tempassuk District.

A herd of kerbaus ${ }^{1}$ wished one day to cross a river but were afraid to do so as there were many small calves in the herd and the river was both swift and deep. As they were debating how they were to cross, some banana trees which were growing near spoke and said, "Cut us down and then you can make a raft from us for your children to cross the river on." So the kerbaus cut down the banana trees and making a raft set the calves upon it. But when the raft got out into the river the force of the stream seized it and carried it down the river to its mouth, where meeting with great waves the raft was dashed to pieces and all the young buffaloes were drowned. Then the kerbaus, being very angry, attacked the remaining banana trees with their horns until none were left standing; and that is the reason why till the present day buffaloes like to knock down banana trees with their horns.

\section{The Orang Utan.}

A legend of Kampong Kiou at the foot of Kinabalu. Told by Yompo.

Long ago some men went into the jungle carrying sumpitans and when they got near to the River Tenokop they heard someone singing pantuns ${ }^{2}$ among the trees. Then they looked and saw an Orang Utan (Kagu) sitting on the ground singing, and this was his song: "First of all I lived at the River Makadou, but I went to the River Serinsin; from there I went to the River Wariu; from the Wariu to the Penataran; from the Penataran to the Kilambun; from the Kilam-

\footnotetext{
1 Buffaloes.

2 A kind of poetry.
} 
bun to the Obang, and from the Obang to the Tenokop. I cannot go up into the trees again for I am old and must die upon the ground. I can no longer get fresh young leaves to eat from the trees; I have to eat young grass." Then the men who had been listening said to one another, "This Kagu is clever at pantuns, let us shoot him with our blow-pipes." One man was about to shoot when the Kagu saw him and said, "Do not shoot me but make me a hut and let me live here till I die. When you have made me my hut, bring your sisters here and I will teach them magic, for I am skilled in it." So the men made him a hut and they brought their sisters to him and the Kagu instructed them how each sickness had its own magical ceremony (menghadji). He taught them the spells for snake bite and fever, and for the bite of the centipede. Then the men went home, about three days' journey, to get rice for the Kagu, but when they came back with the rice the Kagu was dead; and from that day whenever there was sickness in Kampong Kiou they called the women who had been instructed by the Kagu, and those who were ill recovered and if a man was wounded and was menghadjied by the women no blood came from the wound.

\section{The Monkeys.}

Told by Sirinan, a Dusun of K. Piasau, Tempassuk District.

The monkeys were once men. The people who became monkeys were dyeing clothes and while they were working they were struck by hail and became monkeys. Their hands became black from the dye, and so they remain till the present day, and the movements of monkeys' hands still resemble the motion of those of people dipping the cloth in the dye (i.e., the sort of patting motion often made by monkeys with their two hands).

\section{The Singkalaki and His Slaves.}

Dusun legend told by Ransab Orang Tua of K. Piasau, Tempassuk District.

The Singkalaki once wished to set out on a voyage, so he called to his wife, "Baing," said he, "I am going on a voyage, so you must prepare rice for me." When all was ready the Singkalaki took the buffalo fence from below his house and when he had made a raft from it he loaded his rice and other baggage upon it. So he sailed away and after a time he came to an island. There he found a Takang, and taking him on board he bound him to the raft. Sailing away again he came to another island where he found a toad (Buangkut) and this too he bound to the raft before he left. At length he came to a third island and from there he brought away a Padtong. On another island he found a Korutok ${ }^{1}$ and this also

1 All these four animals are species of frogs or toads. 
he loaded on his prahu, and his rice being finished, he then sailed home. When he came to his house he called to his wife, "Baing," said he, "you can carry the four slaves I have got from my prahu." So his wife brought the four slaves to the house. When night came the Padtong began to cry "Tong, tong." Then the Singkalaki called to his wife, "Baing, this slave of mine wants to hang (gan-tongl), me; you had better tell him to run off." Next the Korutok started to cry "Tok, tok." "Ah," said the Singkalaki to his wife, "this slave wants to chop me (Dusun, totok, to cut), you had better throw him out." "Buangkut-kut, buangkut," said the toad, and the Singkalaki called again to his wife, "Baing, this slave too has been plotting with the others and wants to bury me (Dusun, memukut, to dig), throw him out too." But the Takang did not make a sound and the Singkalaki said, "This slave has not been plotting," so when he went to the kabun he took the Takang with him and gave him a parang, but the Takang, not being a man, did nothing with it. Then the Singkalaki said to his wife, "This Takang is new to the work; don't force him, and perhaps to-morrow or the next day he will have learued." So he brought the Takang back to the house and the next day again took him to the kabun and gave him a parang, while he himself and his wife went to work. When they stopped working they went to look at the Takang and finding he had not done any work, the wife said, "Why has he not done any work?" "Oh," said the Singkalaki, " he is new to it and besides he is grieving for his relations." Then the Singkalaki took the Takang and tied him up outside the sulap, giving him a parang so that he might learn to work. After a time it began to rain hard and the Takang started crying "Kang, kang." "Ah," said the Singkalaki, "this is very bad, for he wants to use me as a horse and place reins (kakang) in my mouth." Then the Singkalaki threw out the Takang also and thus had no slaves left.

\section{The Pugou.}

Dusun legend told by Serundai, Orang Tua of K. Kalisas, Tempassuk District.

The Pukou is like a pig in appearance and has a very sharp tongue. If a man is pursued by Pukous, he is safe if he crosses a river. The Pukous eat the bark at the tops of trees and if they want to feed, mount up on one another's backs till the top of the tree is reached and the top Pukou licks the bark off the tree. If the Pukous meet a man they stop, and the man stops; and when the man runs away the Pukous hunt him. Should he climb a tree the Pukous mount up on one another's backs until they have caught him and the top Pukou licks off the flesh from the man's bones. If the man crosses a river the Pukous follow him, but when they get to the opposite bank they stop to lick themselves like dogs and their tongues lick up all their skin and flesh until only bones remain.

1 Dusun, gantong $=$ hang. 
The Mengkahalob.

(Tuaran Dusun version of the Eclipse of the Moon.) $)^{1}$ Told by

Omboi, a Tuaran Dusun.

The Mengkahalob says to its mother, "I've not had enough to eat, I want two jars more." When he has finished the two jars he asks for another. Then his mother says, "What, are you not full yet?" and the Mengkahalob answers "No." "Well," says his mother, "if you are not satisfied yet go and eat the moon." So the Mengkahalob goes and swallows the moon and the Dusun seeing the moon in his mouth beat gongs and drums until he puts it out again.

\section{WILd PIg.}

A legend of K. Lubah told by Sirinan of K. Piasau, Tempassuk District.

A long time ago a man made a kabun and planted it with "ubi kayu" and "kaladi." After a while, when the crop was ready, many wild pigs came and broke into the kabun. Then said the man, "I shall get no food if the wild pigs always come and eat my kaladi." So he made a blatek ${ }^{2}$ in his kabun and when he had set it he went home. The next morning he went to the trap and found that no pig had been in his kabun that night. "Why is this," said he, "that when I have made a trap the pig no longer enter my kabun?" After another three or four days he again went to the trap and he found that a wild pig had been struck by it, but that the head of the bamboo spear had broken off in the wound and the pig had got away. The man followed the track of the pig's blood into the jungle and for four or five days he hunted on its trail, but even then he did not find the dead pig. At last the trail of blood stopped but he still followed the footmarks, which appeared fresh. When he had been on its track for a whole month he at length came to a river with a bathing-place. The man stopped and bathed, but he saw no one on the banks or in the river. Then when he had finished, finding many tracks of men on the bank, he went in search of their houses, for he had lost the track of the pig at the river. For a whole day he sought for them but could not find them, but on the second day he was startled to come suddenly on a kampong where there were many people. The people of the kampong came to meet him and asked him whence he had come; but the man did not answer. "I have never seen you before," said one of the people of the kampong, "and besides strangers never come here. Never since I can remember have I seen a stranger here, for our village is a month's journey from any other." Then the man from Lubah answered, "This is the reason why I have come. I made a kaladi garden and wild pig were always breaking into it. Because of this I made a blatek and I came here hunting for the tracks of a wild pig which was wounded by it." Said a man of the kampong,

$$
{ }^{1} \text { See p. } 433 \text { ante. } \quad{ }^{2} \text { Spring trap with spear. }
$$

voL. XLIII. 
"You can come to my house. There are only a few of us here for many have sailed away to trade, but one man who became sick has returned as he was of no use in the prahu." "What is his illness ?" said the man from Lubah, "and how long has he been ill?" "He has been ill for more than a month," replied the other, "but he only came back two days ago. We have all tried our medicines and he does not recover, but if. you are skilful give us your help." "Where is his illness?" said the man from Lubah. "Below his arm," answered the man of the kampong. So the stranger went to see the sick man and opening his coat saw the sharp part of his spring trap spear sticking in the man's body. Then the man of the kampong promised the stranger a reward if he could heal his companion, and the latter said that he would do his best. So he drew out the spearhead from the man's body and put medicine on the wound, and in two or three days the man recovered and gave the man from Lubah much goods in payment. Thus the man from Lubah knew that the men of this kampong were able to change themselves into wild pigs; and to the present day if many wild pigs come to Lubah, they consider that they are not really pigs but men in the shape of pigs, who have come from some far away kampong to plunder them.

\section{The Legend of Aki Gahuk, the Father of the Crocodiles.}

\section{Dusun story told by Sirinan of K. Piasau, Tempassuk District.}

Long ago Aki ${ }^{1}$ Gahuk was chief of Kampong Tengkurus. He was a very old man and he had seven sons and four daughters. His sons all wished to take wives, and his daughters, husbands, and so they married. At last Aki Gahuk became so. old that he could no longer walk, and his children did not wish to provide for him. Then Aki Gahuk said to them, "Why do you not wish to support me, for I am an old man and can no longer get my living?" But his children answered that they wished he were dead, as he was only an encumbrance to them. So Aki Gahuk wept and said, "If you wish me dead you had better put me into the river, for although you give me food, you give me no clothes and I am naked and ashamed." Then his children put him into the river, for they did not wish to buy clothes for him ; and Aki Gahuk stopped there in the water, and every night and morning they gave him food. There was a large stone in the middle of the stream and when he was cold Aki Gahuk used to climb slowly up on to this and sit there like a toad. Now after he had been in the water for three or four months, Aki Gahuk no longer climbed the big stone and his feet and legs as far as his knees became like those of a crocodile. His children who brought him food saw that his feet had become. like a crocodile's and said, "Father, we thought you would die but you are becoming a crocodile." Then all the brothers and sisters came together to look at their father and said to him, "Father, if you are not going to die, let us take you home again to the house and give you clothes, for we do not wish you to become a crocodile."

$1 \mathrm{Aki}=$ ancestor, grandfather ( $f f$. Abi of the Hebrew), etc. 
But Aki Gahuk said, "How can I go home with you, for I have become a crocodile. Before, you had no pity on me and now that you have pity on me I am unable to go home." So his children wept and said that they did not wish him to turn into a crocodile and Aki Gahuk said to them, "You can tell this story to your descendants; perhaps also it is good that I should become a crocodile. On feast days you can call to me, and when there is a flood I will take you across the river on my back." After some days his whole body became like that of a crocodile and his children were afraid that he would eat men, but he could still speak and he told them that he would never eat men though perhaps his descendants might do so. Then after a year Aki Gahuk called to his children and told them that he wished to go seawards, saying that if his children went in that direction they were to call him, "For," said he, "I wish to take a wife." Said his children, "How will you take a wife for there are no other crocodiles?" "I will call one to me," said their father, "I will call the Pang (iguana) and she will become my wife." Then Aki Gahuk went seawards and the Pang became his wife and from their offspring arose all the crocodiles.

\section{Dusun Signs For Averting Sickness.}

The story of how these work is told by Yompo of Kampong Kiou near Kinabalu.

These signs are set up in time of sickness. Sickness spirits see the signs and meet the spirits which have been called into the spear and figures by the menghadji. ${ }^{1}$ When the spirits of the small-pox are journeying in the countries in companies they come to one of these signs and the spirits of the spear (andus) call to them, "The men of this kampong set us here to dispute (bichara) with you, the men here are our men and you cannot come here." So it is settled that the spirits of small-pox shall not enter the kampong, but they ask the nantus ${ }^{2}$ of the spear to point out a kampong to which they can go, saying, "If you will show us the way to another kampong we will not enter this one." So some of the nantu andus ${ }^{3}$ go with the spirits of small-pox. When they meet with another kampong it is dark to their sight though it is really daylight; for the people of the kampong have set spear spirits there also and have made it dark with their magical ceremonies. Then the nantus of small-pox menghadji ${ }^{4}$ and when they have finished and it has become light again, the small-pox spirits find that they have passed the kampong while they have been walking along performing these rites. [There are nantus of the spear at all the kampongs, but they do not follow the small-pox spirits like those of the first kampong.] When the small-pox spirits come to the third kampong it is dark there also, and the same thing happens again. Then the spirits of small-pox say to the

1 Religious ceremony.

${ }^{3}$ Spear spirits.
2 Spirits.

4 Perform a magical ceremony. 
nantus of the spear, who came with them from the first kampong, "If we cannot get into another kampong we will go back and get into yours." When they are between the third and fourth kampong it is still dark, and they wait there for five or six days and nights to see if it will become light. Then the nantus of small-pox say to the spear nantus, "If we do not get into this kampong we will go back to yours." "Very well," say the nantus of the spear, "we will go with you into this kampong, for we do not wish you to go back to ours." So the leaders of the smallpox spirits and of the spear spirits confer together, and one of the small-pox spirits says, "I will not go back, for we swore not to." Now the road to both the third and fourth kampongs being dark they try to make their way into the latter, but coming upon a very large rock near the kampong they cannot fly over it because it is dark and they cannot see. Then one spirit of small-pox finds a narrow path to the back of the village and follows it with the others behind him, and when they have walked a little they look back and find that it has become light, and they can see the kampong clearly, because there is no spear at the back of the kampong but only facing the road by which the small-pox comes. In the village they see many men, women, and children, and the elders of the small-pox and spear spirits agreeing that it would be good to go into the kampong and not go back, they enter the village, and going into a long house they see many women spinning, but the smallpox chooses only those who are beautiful for his sickness, those who are ugly he does not wish for. Then says the leader of the spear spirits, "I have shown you the way into a kampong, and we will now go home, where next you go is your own affair." So the spear nantus go home; but they become like brothers with the spirits of small-pox and say to them, "When you have finished here you can come to our kampong also." So when they leave the kampong the spirits of small-pox go to another, but they fight with the spear spirits of that village, for they no longer have spear spirits as their guides, and some small-pox spirits are killed and some of the spirits of the spear. After more kampongs, only a few of the spirits of smallpox enter, for many of them have died in the fights with the spear spirits; and at last there are so few spirits left that they no longer dare to attack a kampong.

\section{The Half Men.}

Dusun story told by the headman of K. Tambahilik, Tempassuk District.

Once a woman gave birth to a boy child but one half of it was wanting; it had only one arm, one leg, and half a body and half a head. The child grew up and his tongue and his deeds were equally evil. If a woman were spinning he would get a parang and slash her loom and cloth; and the women of the kampong used to say to him, "You are like a beast; and besides you are only half a man." Then he would be ashamed and think whence he could get his other half. So at last he set out in search of it. All the men knew him in the country, and when he came to a kampong they would say, "Where are you going?" And he would answer, "I am going in search of my other half." Long he journeyed, and at last he came to a 
susendatan, a place where people get water from the river, and there he bathed. As soon as he had finished he set out for the kampong, and soon saw the houses. When he got there, a man asked him what he was doing, and he replied he was looking for his other half. "There is another half man here," said the man of the kampong. Now the half man who was travelling in search of his other half was looking for his right-hand side, and the man in the kampong was without his lefthand side. So the half man who was a stranger asked how they could become one man, and somebody said, "You must wrestle together and then you will become one man." So they wrestled together for a long time, and at last they became one man. Then the "whole man" asked how he was to go home, "For," said he, "I do not know the way." "Why, it is not troublesome for you to go home," said a villager, "your kampong is quite close"; and the "whole man" looking saw his kampong not far off. So he went back, and his father and mother asked him whence he had got his other half, and he said, "I got it from a kampong far away ; perhaps it is Kenharingan's kampong." Then his father and mother were very glad that their son had found his other half.

\section{RAKIAN.}

Dusun legend told by Sirinan of Kampong Piasau, but it is an up-country Dusun tale which is known to the people of Kiou.

Once there was a mangis tree in which there were large bees' nests, and when there was sufficient honey in the nests a man named Rakian went to the tree and began to drive bamboo pegs into it so that he could climb up. It was getting towards evening when he began to work. Now there were many bees' nests in the tree and Rakian, seeing that the bees of the nest right at the top of the tree were white, decided to take it; "For," thought he, "I have never yet seen white bees." Then he climbed up the steps he had made in the tree to take the bees' nest and when he was close he drew his parang to cut it down. But the bees did not swarm out from the nest and while he was sawing away at the branch from which it hung he heard the bees say "That hurts." Then Rakian, wondering, sheathed his parang and the bees said to him, "If you wish to take the nest take it gently and do not cut it down." So he took the nest with the bees in it and putting it into his bareit he descended the tree and went home. When he came to his house he put the bareit with the bees in it into his room. Early the next morning Rakian went to his kabun and did not return until near dark when, on coming back to his house, he found rice and fish ready cooked on his (paha) shelf above the fire. "Then," thought Rakian, "who can have cooked for me for I am the only man who lives in this house: this fish is not mine though the rice is. The rice is cold and must have been cooked for a long time. Perhaps somebody has come here and cooked and taken away my bees' nest." So he went to his bareit and found the bees' nest still there. Then Rakian sat down to eat. "Well," he thought, "if someone is going to cook for me, so much the better." In the morning he ate the remains of 
the rice from the day before, and again went to his kabun. As on the previous day he came home before nightfall and again there was food prepared for him. "Who is this," thought Rakian, "who comes to my house and cooks?" and once more he went to see if his bees' nest had been stolen; and thus it happened that there was always food ready for him when he came home. One day he determined to return early and see who was cooking his food for him. So early in the morning he set out as if for his kabun, but when he had gone a little way he went straight home again and hid himself near the house. For a long time he waited and nothing happened, but at last the door of his house creaked and a beautiful woman came out of his room and taking his bamboo water vessel went out of the house to the river to get water. Then when she had gone down to the river Rakian entered his room without the woman seeing him and went to look at his bees. But when he opened his bareit he found that there were no bees in it, but only the nest. So he took the nest from the bareit and hid it and concealed himself in the house. After a time the woman came back from the river and went to the bareit to look for the bees' nest. "Oh," said she, "who has taken my box (sarong= sheath)?" So she hunted for the nest and at last began to weep, saying, "Who can have taken it? It cannot be Rakian for he has gone to work at his kabun. I am afraid that he will come back and find me." When it was nearly dark Rakian came out from his hiding-place as if he had just come back from his kabun; but the woman sat there without speaking. "Why are you here?" said Rakian, "perhaps you want to steal my bees." "I do not know anything about your bees," said the woman. So he went to the bareit to look for his bees but of course they were not there for Rakian himself had hidden the nest. "Oh," said he, "my bees' nest is not here, perhaps you have taken it." "How should I know anything about your bees' nest," said she. "Well, it does not matter,"'said Rakian, " will you cook for me, for I am very hungry ?" "I do not want to cook," said the woman, "for I am vexed." So Rakian kept on telling her to cook for him, but the woman refused and at last she said, "Where is my sarong?" "I have not taken it," said Rakian. "I believe you have hidden it," said the woman, "and all my clothes and goods are in it." At last Rakian said, "I will not give it to you for I am afraid you will get into it again." "I will not get into it," said the woman; "if you like you can take me for your wife. My mother wished to give me to you in this way because you have no wife here and I have no husband either in my country." Then Rakian took the bees' nest and gave it to the woman. "What is it?" said he. "It is my kawal," replied the woman. "But," said she, "if you take me as your wife do not ever call me a bee woman, for if you do I shall be much ashamed." So they married and had a child. Now one day there was a feast at a neighbouring house and Rakian went to eat there. "Where is your wife from?" said a man at the feast, "for we have never seen such a beautiful woman before." "She is from this kampong," replied Rakian. When all the men had become drunk they still kept asking him whence he had got his wife, and saying that they had never

1 Meaning unknown to Sirinan. 
before seen such a beautiful woman. At last Rakian, who had up to that time always replied that he had taken his wife from the kampong, became drunk also. Then he forgot his promise and said, "The truth is that my wife was at first a bee." So the men stopped questioning him and Rakian went home. When he got to the house his wife would not speak to him. "Why will you not speak?" said Rakian. "What did I. tell you long ago?" said she. "I think you have been saying things to make me ashamed." "I have not said anything," replied Rakian. "You are lying," said his wife, "for though the house is far off I heard. When men asked whence I came, at first you would not tell them, but when you became drunk, then you told them everything." Then Rakian in his turn became silent. "I will go home," said she, "for you have made me ashamed; but the child I will leave with you. In seven days my father will pass to the ulu ${ }^{1}$ of this place on his way home to his country and I will go with him." So Rakian wept. At the end of seven days Rakian saw a white bee flying to the ulu of his house, and his wife came down the steps from his house and saying, "There is my father," she became a bee again and flew off after the other. Then Rakian rushed into the house and seized the child, for it was in his heart to follow his wife and her father, "For," said he, " if my wife is not here the child will die because it is still little." So he hunted for the bees until he saw them going in front of him in the jungle. At the end of seven days he had lost sight of them and still he had not come to any kampong. On the eighth day he came to a bathing-place at a river. Then both he and the child, being hungry and weary, lay down by the side of the river and slept. At last a woman came from the kampong and woke Rakian and said, "Rakian, why don't you go to your wife's house instead of sleeping here with your child, for the house is not far off?" "When I have bathed," said Rakian, " you must show me the way," and the woman replied, "Very well." So Rakian bathed and then he followed the woman and it was not long before they came to a kampong. " That is her house," said his guide, pointing to a long-house, " but her room is right in the middle of it. There are eleven rooms in the house and if you enter it you must not be afraid, for the roof beams are full of bees, but they do not attack men." So Rakian climbed up into the house and found it full of bees, both large and small, but in the middle room there were none. Men in the house there were none, only bees. Then the child began to cry and Rakian sat down. "Otun,"' said a voice in the middle room, "Why do you not come out? Have you no pity on your child who is weeping here?" Then after a time Rakian's wife appeared in the room and the child ran to her at once, and Rakian's heart became light; but his wife said to him, "What did I tell you at first that you were not to tell whence I came? If you had not been able to follow me here, certainly there would have been distress for you." When she had finished speaking all the bees dropped down from the roof beams to the floor and became men. As for Rakian and his child they stayed in the kampong and did not go back any more.

\footnotetext{
1 Up stream. 2 An expression of endearment.
} 


\section{The Origin of a Dusun Custom.}

Told by Sirinan of K. Piasau, Tempassuk District.

Once there was a woman who had newly given birth to a child. The house she lived in was a large one, ten doors long. One day the women of the other rooms were dyeing cloth with "toum" 1 and the men of the house were away hunting, some in one place, some in another. About mid-day it began to rain and with the rain came much thunder and lightning. While it was still thundering the woman who had newly given birth menghadjied in the house and while she was performing the menghadji she saw a woman chasing a boy outside on the ground below, and their appearance was as if they had been quarrelling, for the boy was weeping and the woman kept snatching up sticks to throw at him. But she did not manage to hit him, and she kept calling out, "Stop, stop, for the people here do not know the custom." So the woman who was in the house stopped her menghadji and going to the door called out, "Why are you treating your boy like that?" The other woman stopped and said, "I am treating him like this because you people do not know the custom." "What sort of custom?" said the first woman, and while she still spoke the thunder stopped and the boy also stopped running away. The woman outside answered her, "In this you do not know the custom and that is why my son is fighting me. It is because you women are dyeing cloth when your husbands have gone to hunt, and it would be good if they your husbands were all together in one place in the jungle. See when they come back, some will bring white, some red, and some yellow; these women are dyeing their cloth black." Then the women of the house said, "We did not know of any custom like this. What is it?" The woman answered them, "This is the custom: when you wish to dye cloth (black or blue) you must not take hold of anything white, red, or yellow." Said the women of the house, "Instruct us in this custom." And the woman outside said, "You must keep this custom and it would be good if men did not get hit by things thrown by my son. ${ }^{2}$ If the things he throws about only hit a coconut tree it does not matter, but if they hit a man there will be trouble for that man. Another time your husbands must not be seeking for things to eat, red, white, or yellow, when you are dyeing your cloth black. And do not bring these colours into the house while you are still dyeing cloth." Then the woman and the boy vanished. After a time came the men who had been hunting; four had got a deer ${ }^{3}$ and the other six had brought turmeric and the young white shoots of the Beluno-tree. When the women saw the men coming they called out, "Whatever you have brought from the jungle, do not bring it into the house this night." So the men slept outside with the goods they had brought from the jungle. On the morrow they brought their deer and other things into the house and the women of the house told them how the woman had chased the

1 A kind of indigo.

2 Thunderbolts.

3 Red blood. 
boy. And to the present day women may not touch red, yellow, or white when they are dyeing cloth. [I think that the boy who was being chased by his mother was the Spirit of Thunder. (Sirinan.)]

NotE.-The colours mentioned would appear to be symbolical of a thunderstorm :-

\begin{tabular}{|c|c|c|}
\hline Black or dark b] & e... & $\cdots$ \\
\hline White $\quad \ldots$ & $\ldots$ & $\cdots$ \\
\hline Yellow and red & $\ldots$ & $\ldots$ \\
\hline
\end{tabular}

\section{LoMARING AND THE SPARrows.}

Dusun legend told by Sirinan of K. Piasau, Tempassuk District.

Once a man named Lomaring lived with his father and mother and he had much padi, because he worked hard in his kabun. His mother wished to get a wife for him but in the whole kampong she could find no one suitable. Then Lomaring said to his mother, "If I cannot find a wife here we must search in other kampongs." So they sought in other kampongs near but still could find no one suitable and at last Lomaring said to his mother, "Mother, if you cannot get a wife for me near by, you would do well not to search any more, for it is tiring work." So the three, Lomaring, his father and mother, went back to work in their kabun until their padi was in ear, but before the padi became ripe it was all eaten by sparrows. ${ }^{1}$ Their padi only was eaten, other men's did not suffer. The next year they again made a kabun and again the sparrows came and ate their padi. Then said Lomaring, "What are we to do, there is plenty of ripe padi but the sparrows only eat ours, which is still green?" When the third year came Lomaring said, "We will try once more, but if we fail and the sparrows eat our padi, I will stay no longer in this kampong." Again when it was near harvest. the same thing happened and all their padi was eaten by the sparrows. So Lomaring said to his mother, "I will go and find the sparrows' kampong, for I am very angry." Then said his father, "You are but young, yet I who am old have never yet heard of a sparrows' kampong." " Never mind," said Lomaring, "if I have to search for five years, still I will find it." So Lomaring told his mother to make him seven pairs of trousers and seven coats, and his mother said to him, "Do not work any more in the kabun, for it is useless." Said Lomaring, "After seven days I will set out and I will teach the sparrows to rob us of our padi." "What will you eat on the journey?" said his mother, and Lomaring told her to make him some cakes.

At the end of seven days Lomaring set out and wherever he went he thought about the sparrows and followed them wherever they flew. After twenty days he saw no more sparrows, but still he walked on and for two or three months he journeyed thus. At the end of this time he came to a kampong, and going to it he

1 Burong pipit. 
climbed up into a long house of twenty doors, but there was no one there. One room in the middle of the house was very beautiful; its steps were of iron and its ceiling of looking-glass while the posts were also of iron. Lomaring sat down there and waited, and after a time a chelapa ${ }^{1}$ appeared before him, but he still saw no one. Then Lomaring said to himself, "How can I eat pinang when there is nobody here? If anyone comes they will accuse me of stealing." Now Lomaring had come to the house after mid-day, and when he had been there a short time he was astonished to see a very little rice appear before him and water in a very small golden kettle, but he did not dare to eat since there was no one there. After a long time an old woman appeared in the room and said to him, "Why do you not eat, for I see that you are hungry?" "How should I eat," said Lomaring, "when there was no one in the house ; people would say that I was stealing." So saying he began to eat and though there was very little rice, when he had eaten and drunk his fill some still remained, nor was the golden kettle empty. Having finished he took betel nut and began to ask the old woman where all the people of the kampong had gone and where their kabuns were, "For," said he, "although there is plenty of padi in the house I see no traces of old kabuns." When it was nearly dark many men and women came home, some carrying sacks, some basongs and others bayongs, all full of padi, and after a time came the children of the old woman bringing padi with them also. Now one of her daughters was very beautiful. Then said the mother of the girl to Lomaring, "We have no trouble about making kabuns, for wherever there is padi we also must have a share of it. It is no use concealing it. See how many years you have worked in your kabun and have not got any padi, for it is your padi that my children are bringing home in their baskets. I saw how your mother was searching for a wife for you, and that is why my people, when they had become sparrows, stole your padi, for I wished you to marry my daughter. All the nen in this village wish to marry her, but I can find nobody who is suitable." Then Lomaring was pleased, but he said, "How do you become sparrows?" "Oh," said the old woman, "there is a spring here and when my people wish to get padi they go one by one into the spring and at once become birds; and when they come home with the padi they again go into the spring and become men." So it was agreed that Lomaring should marry the girl, and he took her for his wife. Then said Lomaring to his mother-in-law, "I wish to go back to my kampong to see my father and mother, and $\mathrm{my}$ wife shall come with me, but I shall stop there two or three years." So Lomaring went home with his wife, and his father and mother were rejoiced to see him. They asked him whence he had got his wife; but Lomaring said, "From another kampong," and did not mention anything about the sparrows. That year they made a kabun and not a single grain of their padi was taken by sparrows.

1 Betel nut box. 


\section{The Three RaJahs.}

Dusun tale told by Gergoi of Kampong Nabah.

Long ago there were no men in this country of the Tempassuk; men's first place was at Naragang Nonok, up country. In this village there were many Nonok trees and men lived in them. When the kampong was over full they called a council and they agreed to divide the country between them. So three men with their wives and children and followers set out at different times from the kampong. The first man who started at length came to a place where there was a threefold fork in the road; he kept straight on and set a mark on the road by which he had travelled. The second man chose the road to the left hand, and the third took that to the right. So the companions of the first man followed him along the straight road and at last they made a village. The parties of the second and third men, who had gone to the left and right, also made kampongs. Seven days after the first man had made his kampong a white stag came to the place. The men of the kampong agreed to try and catch the stag, but it always escaped them, although it did not go far away from the village. Now the name of the man who followed the straight road was the Rajah Kapitan and he had seven wives, and he said to them, "I cannot catch this stag; you had better make me some cakes of banana and flour" (linobok). Then the Rajah, taking with him seven cooks to carry his food and baggage, got on his horse and set out to hunt the stag. So he hunted, and at night the Rajah and the stag both stopped. The next morning, early, as soon as the Rajah had eaten, he again started off after the stag and for three days he chased it, but at last he lost it. Then the Rajah, finding that he did not know where he was, agreed with his men to push on till they should come to some kampong, if there was one. At last they came to a kampong and the Rajah said, "Why, there are other people in this country; I thought that my village was the only one." Then he asked in the village whose it was, and he was told the Rajah Kretan's, " and that the Rajah had seven wives. "Well," said the Rajah Kapitan, "if it is true that he has seven wives, he is like me, and I will ask him for betel nut, telling him, if his wives come to me, to send those that are the most beautiful." So the Rajah's two most beautiful wives came to him, one to give him betel nut and the other to make him roko.2 They were lovely, one as a star and the other as the moon. The Rajah Kretan, however, slept in his house. When the two beautiful women had waited upon the Rajah Kapitan he immediately killed them both and cutting off their heads started for home. This he did because he was angry at losing the stag. Then the Rajah Kretan awoke and when he found what had happened he caught his great dog and using it as a horse pursued the Rajah Kapitan. Now the Rajah Kapitan, who was afraid of being attacked because of the heads he had taken, when he had got home made a fort

${ }^{1}$ Kretan $=$ shark.

${ }^{2}$ Roko $=$ native cigarettes. 
three fathoms in height. So the Rajah Kretan came to the fort, and his dog jumped the wall. When he had got inside he asked whose kampong it was, and men answered "The Rajah Kapitan's." "How many wives has he got?" he asked, and a man answered "Seven." "If that is so," said the Rajah Kretan, "let them bring me roko and pinang." So the two most beautiful wives of the Rajah Kapitan came out to give him roko and pinang, and when he had been served he immediately cut off their heads, and leaping on his dog called out that he was now avenged on the Rajah Kapitan. The dog took the wall at a leap and in a little time the Rajah Kretan was nearly home. Now the Rajah Kretan was the second man who had started from Naragang Nonok, but the Rajah Kapitan knew nothing of the other men who had followed behind him. When the Rajah Kapitan awoke, for he had been asleep, he asked where his two favourite wives were, and he was told how they had been killed. So he started out alone on his horse to hunt the Rajah Kretan and overtook him just as he was going to enter his house. Then the Rajah Kretan seeing him, threw the heads on the ground and made off on his dog, and the Rajah Kapitan hunted him on his horse. After they had been going thus for a week, the Rajah Kretan runuing away, and the Rajah Kapitan pursuing him, they left the Rajah Kretan's country behind and came out upon a plain. So the Rajah Kretan dismounted from his dog and the Rajah Kapitan from his horse and the two fought, but neither conquered the other. Now while they were still fighting they came into a kampong but did not know it until they struck their backs against the posts of the houses. And the men of the kampong were astonished for they saw that the two men were strangers. Then the Rajah Bassi, who was the Rajah of the village, awoke, and coming out of the house, asked why they were fighting, and the Rajah Kapitan told him how he had hunted the stag and how being angry at losing it he had cut off the heads of the Rajah Kretan's wives. And the Rajah Kretan told him how he had avenged himself on the Rajah Kapitan, and how the latter had pursued him. Then said the Rajah Bassi, "Do not quarrel any more about your wives, for I have twenty-seven who are all beautiful and you can replace your dead wives from them. This only, I beg, do not fight in my country." So the Rajah Bassi's twenty-seven wives came out of the house, and the Rajah Kapitan and the Rajah Kretan each chose two wives like their former wives in appearance. And the Rajah Bassi said, "I have given you wives and you must fight no more ; for we three men all came from Naragang Nonok, but I only know the way back. You, Rajah Kapitan, have become aDusun, you, Rajah Kretan, have become a Mohamedan(Bajau, Brunei, etc.), while I have become a white man; and in future time if I have any trouble you must give me your help." Then the Rajah Kretan and the Rajah Kapitan thanked him and promised to help him. "For," said they, "you have become a great Rajah and we will help you; and you shall judge us and our children and shall help us in time of sickness." So the Rajah Bassi said that their answer was good and that they should help him and that he would judge their peoples and give them help, "And," said he, "you must pay me a yearly tax on each head (male) of your people." And so to the present day the Rajah Bassi (the white people) judge the 
Rajah Kapitan (the Dusun), and the Rajah Kretan (the Mohamedans) and take a tax from them for each man. Further he spoke, saying, "There shall be in this pelompongl many people, for that is my wish." So we Dusun to the present day are descendants of the Rajah Kapitan and the Bajau of the Rajah Kretan, and as the white people are the descendants of the Rajah Bassi we obey the Government and clean the paths and do other work in which the Government asks our help. For the Rajah Bassi said, "Though you have made me great I am mortal and shall die, but I will tell this story to my grandchildren, and you, Rajah Kapitan, and you, Rajah Kretan, shall tell it to yours and they shall observe it."

\section{The Magical Prahus.}

Story told by a Dusun of K. Tambahilik, but probably of Illanun origin.

A man named Lomaring once made a beautiful gobang,' and when he had finished it he ordered it to sail away. The gobang set sail of its own accord, and sped over the sea until it came to a rajah's bathing place on the coast, and there it waited. Soon a beautiful young woman, the rajah's daughter, came down to the pengkalan to bathe. "Whose gobang is this," said she, "which has floated away? What a nice plaything." Speaking thus she climbed on board, and immediately the boat sailed away to Lomaring, taking the woman with it. When the prahu arrived at Lomaring's pengkalan he was bathing there, waiting for it to return. "Oh," said he, "perhaps this is my prahu, which is bringing a beautiful woman." So he took the woman and brought her home to his house and made her his wife. Now another man of the same village, Tamburun by name, who was also a young bachelor, but very ugly, heard of Lomaring's luck with his prahu. "Ah," said he, "I also will make a prahu and try my fortune." So Tamburun made his prahu, and ordered it to sail away for him, but for seven days the boat refused to move. Then said Tamburun, "If I talk Dusun perhaps it does not understand, I will try Illanun." So he spoke to it in Illanun, saying, "Go and find a beautiful house," and immediately the boat sailed away, until, at last, it came to a place where a large prahu was moored, which had a dead woman on board. "Ah," said a man on the large prahu, who had caught sight of the gobang, "what luck, here is a small boat in which I can row the dead woman ashore." So he put the corpse into the gobang and immediately it rushed away with its freight to find Tamburun, and arrived at his pengkalan just as he was going to bathe. Tamburun seeing his boat with a woman on it, went and raised her up, but since the corpse could not stand, he said, "Perhaps she is fast asleep ; let her rest for she must be tired." So the dead woman remained on the prahu. On the following day Tamburun went down to the boat again, and the woman's stomach being near bursting, he said, "What a wretch is this gobang of mine; it has brought

1 Pelompong=island, i.e., the country around Mt. Kinabalu.

2 A kind of small boat. 
me a dead woman"; and, getting angry, he broke up the boat. Then Lomaring made a beautiful basong, and when it was finished it started off of its own accord. Now there was a Bajau woman in a village who was making cakes for a festival, and the basong having come into it, stopped there. So the woman, seeing the basong, took it and placed cakes in it, until it was full to the top. Then the basong set off immediately for Lomaring's house, and when he saw it he said, "What sort of basong is this? As soon as I finish making it, it ran off, and now here it is again, full of cakes." So Lómaring and his wife ate their fill. "My prahu," said Lomaring, "got me a woman, and now my basong brings me cakes." Tamburun heard that Lomaring's basong had come home full of cakes, and he said, "I made a prahu to get me a woman, but it only got me a rotten corpse; perhaps I shall have better luck if I make a basong." Then Tamburun made a basong, but when it was finished, it would not go where it was ordered. " "Perhaps," he said, "I must speak Illanun to it," so he said in Illanun, "Basong, go and get food for me," and the basong started off, and went after a herd of cattle, and as it followed close behind them, their droppings kept on falling into it. When the basong was full of dung it went into the jungle and under bushes until the top was covered with leaves, and the dung. could no longer be seen. Tamburun saw the basket coming when it was still some little way from his house, and said, "I will go and help the basong for it cannot climb up into the house, since it is so full of cakes." So he went and carried the basong into the house, and plunging his arm into it to get the cakes he brought it out covered with cow dung. "What a rascal is this basong," said he, "it has brought home only filth"; and he fell upon it with his parang.

\section{SERUNGaL.}

Dusun legend told by Sirinan of K. Piasau, Tempassuk District.

"Ah," said Serungal, "it is no use my stopping here, I had better go and marry a Rajah's daughter." Now Serungal was a very ugly man to look at. So he set out for the Rajah's kampong. After a time he came to a village near a river and hearing men screaming out, he went to see what it was, and saw many men killing an ant. "Why are you doing that?" said Serungal, and the men ran off and left the ant, which crawled away. When he got to the bathing-place of the village, he again heard men shouting. "Why is this?" thought Serungal, and again he went to see what it was. When he got to the place, he saw men trying to kill a fire-fly (nenekput ${ }^{1}$ ). He spoke to them, and as before, the men ran away. At length he came to another kampong, and for the third time he heard men calling out near the river, and going towards the sound, he saw many men trying to kill a squirrel. "Do not do that," said Serungal, and the men at once ran away.

1 Nini is Dusun for an ancestor, and the firefly is said to be a spirit of an ancestor. 
After a long time, Serungal came to the Rajah's palace, and the Rajah said to him, "Serungal, whither are you going?" “Well," said he, "I will not hide my intention; I came to ask for your daughter to make her my wife." Said the Rajah to him, "You see this bayong full of rice. If you can collect it all after a man has scattered it from horseback and put it all back into the bayong until it is full, you shall have my daughter." Then thought Serungal, "How can I collect that rice, if it is scattered from horseback?" but at length he said, "I will try, for," thought he, "if I cannot collect it all I will go home, for I shall not wish to stop here any more." So the Rajah ordered a boy to take a horse and scatter the rice as the horse ran, till it was all finished; and a boy took a horse and scattered the rice in the plain, till it was all finished. "Now," said the Rajah, "I will go home and wait for you for two or three hours, but if you do not collect all the rice, you shall not have my daughter." Then Serungal started to collect the rice, but at the end of half an hour he had only got about a coconut-shell full, and he began to weep. After a time came the ant, and said to him, "Why are you crying?" "Because the Rajah will not give me his daughter," said Serungal, " unless I collect this rice, which he has had scattered, and I have only been able to find a coconut-shell full in half an hour." "Well, stop crying," said the ant, " and I will help you, for you helped me when the men wished to kill me." Then the ant called his companions, and they collected all the rice, until the bayong was full; and Serungal carried the rice home to the Rajah's house. The Rajah saw him coming from far off, and wondered; but when he arrived, the Rajah said to him, "You shall have my daughter, but you must climb my betel tree first, and get me betel nut to eat." Now the Rajah's betel tree was so high that its top was in the clouds and could not be seen. When Serungal saw the tree, he said to himself, "How shall I climb this tree, for I shall fall before I get half way up." So the Rajah went home, and Serungal began to climb the tree, but when he had got about two fathoms up it, he fell to the ground. Then he began to weep; but after a time the squirrel came and asked him why he was crying, and Serungal told him how the Rajah had ordered him to climb the tree before he should have his daughter. "Well," said the squirrel, "I will help you," and he climbed the tree, and brought Serungal the fruit until there was none left. When Serungal was still far from the house the Rajah saw him and said, "This man is greater than I, for he has got the betel nuts which so many men have tried to reach in vain." So the Rajah told Serungal that he could have one of his daughters. Now the Rajah had seven daughters, and it was the seventh and most beautiful of whom Serungal had heard. Said the Rajah, "You must go to my house, when it is dark, and the first daughter of mine you find in the sleeping room shall be your wife, and you must carry her away to another room, but you must come late at night, when it is very dark." "Ah," thought Serungal, " how shall I find his seventh daughter, for if it is dark I shall not be able to see?" That night Serungal went to the Rajah's house and waited outside till it should be dark enough, and he began to weep, because he did not know how to find the Rajah's youngest daughter. At last the firefly came and 
asked him why he was crying; and Serungal told him how he had to take the first of the Rajah's daughters to whom he should come, and how he wished to get the seventh. "Never mind," said the nenekput, "I will search for you, and I will settle on the nose of the seventh daughter; so wherever you see a light, that will be the place where the Rajah's youngest daughter is." Then Serungal went into the women's sleeping room, and seeing the nenekput, carried away the woman on which it had settled to another room. In the morning, when the Rajah came to see which daughter Serungal had chosen, he found that he had taken the youngest and most beautiful. And thus the Rajah was forced to acknowledge him as his sonin-law.

\section{Ginas AND the RaJah.}

Dusun legend told by a man of K. Tambahilik, Tempassuk District.

A long time ago there was a man and his wife whose names were Rakian and Sumundok. ${ }^{1}$ On the day when they married many others also had married and each couple had at least two children, but Rakian and Sumundok had none, though Sumundok was expecting a child. Rakian fell ill, and he said to his wife, "Perhaps I shall die before I see my child, but you must bring him up well, for we are not wanting in possessions." Then Rakian died and after a time Sumundok gave birth to a male child, and she said to it, "I will give you a name; your name is Ginas, but I will not bring you up, I will put you in a box." So Sumundok put the child into a box, and after two or three months she went to look at it and found that it had grown and could walk. When the child had come out of the box it spent its time in hunting the pigs and its mother did not forbid it, "For," thought she, "if it should kill a pig, I can replace it." But the people of the kampong became angry because Sumundok's child was always chasing their pigs. One day Ginas went to the Rajah's house, and for two days he hunted the pigs there below the house. Then the Rajah said to one of his men, "Go to Ginas's house and tell his relations that he must not hunt pigs any more, for I have had no sleep from it for two nights. If he does not follow my orders I will make him my slave." So three men went to Ginas's house and told him that if he chased the Rajah's pigs any more he would make him a slave. But Ginas paid no heed to the Rajah's words, and going to the Rajah's house he again hunted the pigs. Then said the Rajah, "All men follow my orders, this Ginas only, who is still small, does not obey me." So the Rajah sent to Ginas saying, "For three nights I have not been able to sleep for the noise of the waves in the sea. Go and chase them and see if you can stop them." When the Rajah's men came to the house of Ginas they said to him that the Rajah wished him to stop the waves, and Ginas said, "You must stop here to-night and eat with me." The three men stopped there; and when it was night Ginas went down to the sea-shore, and, taking sand, wrapped it in his handkerchief. Then

1 Sumundok= virgin? 
going back to the house, he woke the Rajah's men and said to them, "Give this sand to the Rajah and tell him to have a rope made from it and when the rope is marle I will use it to catch the waves with." So the men went home and the Rajah asked them what Ginas had said to his order to stop the waves. Then the Rajah's men told him that Ginas had said that he would catch the waves, only that as he was short of rope he was sending some sand to the Rajah of which to make a cord, and that when the cord was made he would catch the waves with it. And the Rajah had to admit that he was beaten, and threw the sand away. Then the Rajah had seven jars of Tapai made, and killed three cattle; then he sent three men to call Ginas to drink. The three men came to Ginas and he replied that he would come on the next day. On the morrow, Ginas brought out clothes all covered with gold, and, putting them on, set out. When he got to the Rajah's house the Rajah asked him to sit down on his mattress, and all kinds of food and drink were brought to them, and there was a bowl there for washing the hands, seven punkals ${ }^{1}$ in circumference. After they had eaten, the Rajah said to Ginas, "Ginas, you shall wash your hands on my mattress, and if the mattress is not wetted you shall replace me as Rajah, and shall have all my property and my daughter for your wife; but if you wet the mattress you shall become my slave." So when Ginas was washing out his mouth he was afraid to spit the water out on to the mattress, so he sent it into the Rajah's face instead, saying, "I was afraid to put it anywhere else, but your face does not matter, since you are blind in one eye, and thus your face is damaged. Take this looking-glass and look." So the Rajah took the glass, and, seeing that one of his eyes was damaged, and that no one else had so ugly a face, was ashamed and ran away from the country, taking with him only one of his wives. As for Ginas, he took his place and became Rajah.

\section{Todu.}

In May, 1911, I made some small excavations on the site of a legendary Dusun kampong which is situated not far from Piladok, an Illanun village in the Tempassuk district. The following story is told about the place. The name of the old kampong is Tudu.

Long ago some men of Kampong Tudu were looking for wood to make a fence, and while they were searching they came upon what appeared to be a great tree trunk, which was lying on the ground. They began to cut it with their parangs, intending to make their fence from it, but to their surprise blood came from the cuts. So they decided to walk along to one end of the trunk and see what it was. When they came to the end they found that they had been cutting into a great snake and that the end of the "trunk" was its head. They therefore made stakes and driving them into the ground bound the snake to them and killed it. Then they flayed the skin from the body and taking it and the meat home they made a

1 Spans. 
great feast from its flesh. The skin of the snake they made into a great drum, and while they were drinking they beat the drum to try its sound, but for a long time the drum remained silent. At last, in the middle of the night, the drum began to sound of its own accord, "Duk, Duk, Kagu'; Duk, Duk, Kagu." Then came a great hurricane and swept away all the houses in the kampong; some of them were carried away out to sea together with the people in them, others settled down at what is now Kampong Tempassuk and other places, and from them arose the present villages.

The excavations yielded sufficient evidence of former occupation of the site. Tudu is at the top of a large lalang'-covered hill, perhaps 1,000 feet in height. On the summit are two large impalum (a kind of mango) trees of great age. Having selected a probable hơuse site, I drove two parallel trenches across it and many shells of sea molluscs were at once found as well as those of the large freshwater snail which is so much used as an article of food at the present time. There were also many fragments of cooking pots and these were of a much thicker make than those at present in use among either Dusun or Bajau. Two pieces of light greenish porcelain of evident Chinese manufacture were also discovered and were said by the Dusun coolies to be respectively fragments of a gusi ${ }^{3}$ and a tompok, ${ }^{3}$ but this I consider doubtful, although the fragments are undoubtedly ancient. A large circular stone of syenite which has the appearance of being waterworn was also found, and the opinion of the Dusun coolies was that it was a potting stone, such as is used by the natives for smoothing the inside of pots. The most important relic, however, was a more or less circular stone, which had a chiselled depression in the centre on both sides; and these were evidently intended to give a firm grip to the fingers. Native opinion hesitated for some time as to whether or not this also was a potting stone, but eventually came round to my point of view that it was probably a hammer stone used for breaking open sea-shells. All the Dusun agreed that they had never seen anything of the sort before. Below the hill on which Tudu stood are two largish pools and at some distance from them a stagnant and winding watercourse. These two places are pointed out respectively as the spots where the snake was first wounded and where it eventually died.

\section{LAMONGOYON.}

There is an earthwork some little way above Singarun rest-house in the "Ulu Tempassuk" into which the bridle path of the interior now cuts. It consists as far as can now be seen of a ditch and mound on the hillside, the ditch being on the upper side of the mound. I have measured both of these and find them to exceed 60 feet in length. The mound has been much damaged by the

1 Kagu is Bajau for hurricane or typhoon.

2 A very wiry kind of grass.

3 Sacred jars. 
construction of the bridle path but appears not to have been of any great breadth. Unfortunately I have not been able to make excavations there, but the Dusun tell the following legend concerning the spot:-

There was once long ago a very tall man named Lamongoyon. He could cross a river at a single stride and he died on top of the hill where his grave is. His people were unable to lift his body and so they rolled it down to the place where they had made his grave, and there he lies to the present day. His head points inland and his feet seawards.

\section{Plandok Stories.}

\section{The Plandok and the Gergasi.}

Bajau story told by Si Ungin of Kotabelud.

Once upon a time there were seven kinds of animals, the kerbau (buffalo), the sapi (ox), the dog, the stag, the horse, the plandok (mouse-deer), and the kijang (barkingdeer, Cervulus muntjac). These animals agreed to catch fish and when they had cast a round net into the sea they drew it to the edge and there were many fish in it. They placed their fish on the sand, and someone said, "Who will guard our fish while we go and cast the net again, for we are afraid of the gergasi." Then said the kerbau, "I will guard the fish for I am not afraid of him, if he comes here I will fight him with my horns." When the other animals had gone away the gergasi came and said, "Ha, ha, ha, what a lot of fish you have caught! I'll eat them directly, and if you don't like it I'll eat you too." Said the kerbau, "All right, come here and I'll horn you." "Very well," said the gergasi, "if you won't give me your fish I will eat you." When the gergasi had got close, and the kerbau made as if to horn him, he seized hold of its horns and the kerbau could do nothing, because the gergasi was very big and strong. Then the kerbau cried out, "Let go; if you let me go you can eat the fish." So the gergasi let him go and the kerbau swam off to his companions, who were in the sea catching fish. When he came there, he said to them, "The gergasi has eaten our fish; he caught hold of my horns and I could do nnothing." Then the other animals were angry with the kerbau and said, "If we were to go on fishing till we died the gergasi would get all our fish"; and the horse said to him, "You fish with these others this time; I'll guard the fish, and if I don't manage to bite the gergasi at any rate I'll kick him." So the animals brought the fish to the same place and leaving them there in charge of the horse went again to catch more. When the other animals had been gone a good time, out came the gergasi again, and said " $\mathrm{Ha}$, ha, ha, if you don't swim off again to your companions, I'll eat you as well as the fish." "Well," said the horse, "come and take them if you can, but I will guard them till I die." On the gergasi's approach the horse tried to bite him; but the gergasi caught bim by the head and he could do nothing. Then the horse reared up and the gergasi let go his

1 A mythical giant who carries a spear over his shoulders. 
head. When he had got free he let fly at the gergasi with his heels but the gergasi caught him by the hind legs. So the horse begged to be let go and the gergasi let him go, and while the horse was swimming away to his companions the gergasi ate the fish. When the horse reached his companions he said, "I too have done my best, but the gergasi has got the fish. First I tried to bite him, and he caught me by the head. Then I reared and, having shaken him off, tried to kick him, but he only caught me by the legs, and I had to give in." Then his companions said, "What is the use of our catching fish, we only get tired and the gergasi eats them; it is best that we should go home." So the sapi, the stag, the dog and the kijang said, "What is the use of our trying to fight the gergasi, for we are afraid; all the strong animals have tried but they have all been beaten. Let us go home." The plandok only remained silent, and when all the others had had their say he said, "You go and catch fish again and I will stop on guard." "What can you do," said the horse, "who are so small? How can you fight the gergasi ?" "Never mind," replied the plandok, "I can't fight him or kill him but I should like to guard the fish." The other animals wanted to go bome, but the plandok persuaded them and they again caught many fish and these they placed on the sand in the same spot. Then said the stag, "Who is going to guard the fish?" and the kerbau replied, "Why the plandok said just now that he would." "Very well," said the plandok, "I will guard them but perhaps some other animal would prefer to, as my body is so small." But none of the other animals were willing, so the plandok said, "All right, I will guard them, but put them in a heap and cover them with leaves so that they cannot be seen." Then his companions heaped up the fish and covered them with leaves and having done so went back to the fishing. When the others had gone the plandok went and got some rattan and cut it into strips such as are used for binding anything. As soon as he had finished, out came the gergasi and said, "Ha, ha, ha, is the plandok guarding here? Why, I got the fish from the kerbaw and the horse, what do you think you, who are so small, can do? You had better give me the fish or I'll eat you along with them." Then the plandok said, "I'm not guarding the fish, I'm working cutting up rattan," and the gergasi, who had come near but had not seen the fish said, "What are you doing with the rattan?" "I'm binding it round my knees," replied the plandok. "Why are you doing that?" said the gergasi. "Don't you see the sky?" said the plandok, "it looks like falling, see how low it has got; that's why I am binding up my knees." "Why do you bind up your knees if the sky looks like falling?" asked the gergasi. "I'm binding up my knees so that I can get into our well here; for, if the sky falls, I shall not get hurt when I'm down there." Then the gergasi looked at the sky and saw that it was very low. " Don't bind up your legs first," said he, " bind mine." " All right," said the plandok, "only go over to the well first." So the two went to the well, the plandok carrying the rattan. Then the gergasi said, "You bind yourself up first," but the plandok replied, "If I bind myself up first how can I bind you up afterwards." "Very well," said the gergasi, " bind me first, but you shall be the first to go into 
the well." "If I do that," said the plandok, "I shall not die from the sky falling on me but from your falling on top of me in the well." So the gergasi agreed to go first as what the plandok said seemed reasonable; and the plandok bound up the gergasi firmly, tying his hands to his knees. "Why have you bound me so tightly?" said the gergasi, but the plandok only gave him a push and he fell into the well. "Ah, now you can stop there till you die," said the plandok; "you don't know the plandok's cleverness." "I suppose I shall die here," said the gergasi. "Yes," said the plandok, "for you have always stolen our fish." After a little time there came the plandok's companions, bringing more fish. "Ah, see how clever I am," said the plandok, "for I have bound the gergasi! You said the gergasi was strong. How then have I managed to tie him up?" "You lie," said the kerbau, and the horse, "How could you manage to bind him." "If you don't believe me," said the plandok, "look into that well and see if he's not there." So all the animals went to the well and saw the gergasi. Then said the horse and the kerbau, "How did you bind him?" "What's the use of your asking," said the plandok, "you don't know the plandok's cunning. However, you'd better kill him with a spear or something because he's stolen our fish so often." So they killed the gergasi with a spear. When the gergasi was dead they agreed to eat on the shore, and when they had cooked their fish and rice they found only one thing wanting, and that was pepper. So as they had no red pepper they did without it, though as they were accustomed to it they did not enjoy their food so much. Then while they were eating, the plandok saw that the end of the dog's penis was showing red, "Ah," said he, "we were seeking for red pepper just now-there is some I see." And he pointed to the dog's penis. (Nampak itu anjing punya butu sudah kluar merah. "Ah," di a bilang, "Kita orang mon chari lada merah tadi, sana ada lada merah, sahya nampak" - dia tunjuk itu anjing.) The dog did not understand and the stag and the kijang said, "Where is pepper." "There," said the plandok, and he again pointed to the dog. Then the dog became very angry because he was ashamed and the stag and the kijang had laughed at him. Then the stag, the kijang, and the plandok became frightened and ran away and the dog pursued them. And the dog always hunts these three, till the present day, because they made him ashamed. The dog was hot on the track of the plandok when they entered the jungle. The plandok, however, managed by using its teeth and feet to climb a tree. The dog came below the tree but could neither see the plandok's tracks nor follow its scent beyond this spot. So the dog left following the plandok and went to hunt the stag and kijang. When he got to the place where the animals had fed he found that they had all gone but their fish and rice were left behind. Then he hunted the stag and the kijang but could not catch them. At last he said, "Well, if I ever see either the stag or the kijang or the plandok I will kill them, and my children and their descendants shall do the same." And so they do down to the present day. A little time after the dog met the horse, the kerbau and the ox and these four animals shared the food, for the dog was not angry with them, because they had not laughed at him. 


\section{The Plandok and the Tiger.}

\section{Told by Si Ungin, a Bajau of K. Kotabelud.}

When the dog had gone home the plandok went in search of the tiger, and on his way he came across a lot of snakes which were lying coiled up in circles near the tiger's house. The plandok waited there and the snakes did not move. Then came the tiger, and the tiger and the plandok saw each other at the same moment. The tiger, however, did not see the snakes, and said to the plandok, "Plandok, what are you doing here?" "Oh," said he, "I've been waiting here a long time on guard, because the Rajah has ordered me to." "What are you guarding?" said the tiger. "I am guarding the Rajah's goods here, his oruts," said he, pointing to the snakes. Then the tiger looked at the oruts, and seeing them coiled up, he said, "What if we drag them undone, then I can tie them round my waist and see if they are good ones or not." "I dare not let you do it," said the plandok, "as the Rajah has put me here to guard his goods, but if you like I will ask him." Now the plandok was frightened of the tiger and wanted to beat a retreat, so he said, "I will go ahead, and if I meet the Rajah I will call to you." Then the plandok started in search of the Rajah, and when he had got some little way off, he called to the tiger and said, "I have met the Rajah, and he says that you can try on the cloths." Then the tiger canght hold of the snakes and dragged at them, and they, waking, attacked him, winding themselves about his body and biting him. Thus the tiger died. As for the plandok he ran off, saying, "Ah, you tiger, you consider yourself strong, don't you? but you are no match for the cunning of the plandok."

\section{The Plandok and the Bear.}

\section{Told by Si Ungin, a Bajau of K. Kotabelud.}

When the tiger was dead the plandok began to think how he could get the best of the bear, for he had heard that the bear was also a strong animal. As he was walking along one day he came across a bees' nest in a tree, and sat down near it to wait. After he had been there for some time there came the bear. "What are you doing here?" said he. "I am guarding the Rajah's tawag-tawag," answered the plandok, "which he has left in my charge." "May I try its sound," said the bear, "whether it is good or not?" The plandok answered as before that he must ask the Rajah first, and when he had gone off and had got some distance away, he called out, "The Rajah says you can strike the gong." So the bear struck the nest and the bees, coming out in a fury, stung him to death.

1 Orut, a long scarf-like cloth used for swathing the body and especially the stomach during war. It is said that if a man who is wearing an orut is stabbed in the abdomen, no intestine will project from the wound. 


\section{The Plandok and the Crocodile.}

\section{Told by Anggor, a Tuaran Dusun.}

The plandok was walking one day near the edge of a river and he saw some fruit on a tree on the other side. He was just going to cross when he saw the crocodile. "Who is that?" said the plandok, but the crocodile did not answer. Then said the plandok, "Ah, I know who you are, you are the crocodile. In seven days' time I will bring my whole tribe to fight you, and do you also bring your people." When the sevènth day had arrived, the plandok went down to the river very early, before the crocodile had come, and walked backwards and forwards until the whole of the river margin was covered with its tracks. After a time the crocodile and his companions arrived. Then the plandok, who was awaiting them, spoke and said, "You are late in coming; my followers waited and waited for you, but at last they grew tired and have gone home. If you do not believe me, look at their tracks on the bank. I should like to count how many you and your companions are, so draw yourselves up in a row from one side of the river to the other." So the crocodiles did so, and the plandok started walking on their backs counting "One, two, three," when suddenly he gave a jump and reached the other bank. Then he called out, "Ah, I have cheated you, for how else could a plandok fight with crocodiles. I saw the fruit on the other side of the river, but I was afraid to swim across as I knew you were waiting for me." "Very well," said the crocodile, "wait till you come down to the river to drink and I'll eat you." A few days afterwards the plandok, who had forgotten about the crocodile, came down to the river to drink, and the crocodile caught him by the leg. Then the plandok took hold of a piece of wood and pulled it towards him, and when he had done this he called out, "That is not my leg you have caught hold of ; this is my leg," said he, pointing to the piece of wood. So the crocodile let go of the plandok's leg and the plandok sprang away, calling out, "Ah, I have cheated you again, how foolish is the crocodile!" "Very well," said the crocodile, "another time I won't let go of your foot so easily."

\section{The Plandok and the Omong.}

\section{Story told by Si Ungin, a Bajau of K. Kotabelud, Tempassuk District.}

When the plandok had cheated all the strong animals and had brought about their deaths, he wished to have a contest of wits with an animal who considered himself clever, so he went in search of one, and at last he met the omong, ${ }^{1}$ and the omong said to him, "Plandok, all the strong animals have been killed by your cunning, but if you like to try your wits against mine, I am ready." "Very well,"

1 Omong, the hermit crab. 
said the plandok, "that is just for what I am looking, animals who consider themselves long-headed; but how would you like to compete with me?" "I should like to race you," said the omong, " and if you win I will acknowledge your cleverness and your power of running." "What, you want to race with me?" said the plandok, "you can only walk sideways on the sand, and you don't race with your body only for you have to carry a shell as well." So the plandok felt ashamed to run a race with the omong, but he said, "When are we to race?" "To-morrow," replied the omong, "we will meet in the middle of the sands and race. You had better call your companions and I will call mine too." "Very well," said the plandok, "I will come to-morrow." "We will make a four-sided course for the race," said the omong, "and we will race along the sides of the square from post to post." On the morrow the plandok and his companions came, and also the omong with his, and it was decided that whoever won should be considered the champion over all the animals--for the plandok had already overcome all the strongest of them. When they arrived at the open sand by the sea they made a square, placing stakes at the corners. Now the plandok collected all his followers into one place as did also the omong. The omong, however, had made a plot and chosen three of his companions like him in appearance and size, and had told them to bury themselves in the sand by three of the corners of the racecourse, but to leave the fourth corner, the starting-point, vacant. Then said the omong to the plandok, "When you get to the first post call out, 'Omong,' and if I don't answer you will know that I have been left behind and that you have won the race." So the plandok and the omong started to race from the first post, the omong saying, "Run." When the plandok heard the omong say "Run," he gave a jump and the omong, who of course was left behind, quickly buried himself in the sand, without anyone seeing him; for the spectators were some way off and the omong small. So the plandok ran without looking back, and when he got near the first post the second crab had come out of the sand and was waiting for him. When the plandok got to the post he called out, "Omong," and the crab answered, "Yes." So the plandok seeing what was apparently the same crab gave another jump and started running for the second post. The same thing happened here also, and the plandok said to himself, "How is it that the omong who walks so slowly manages to keep up with me?" At the third post the crab again answered, and the plandok, who was breathing heavily from running at top speed, set off as fast as he was able, for the original starting-post, which was also to be the finish of the race. When he got there the omong was waiting for him, and again when the plandok called out, "Omong," he was answered. Then the plandok was ashamed and wished to die, so he ran from stake to stake until his breath was exhausted, and when he reached the startingpoint he called out again, "Omong," and the omong answered, "Yes." Thereupon the plandok, who had no breath at all left, fell down and died, and the omongs cried out that the omong was the champion; but the plandok's followers kept silence. 


\section{The Plandok in a Hole.}

\section{Told by Orang Tua Ransab, a Low-Country Dusun of Kampong Piasau, Tempassuk District.}

The plandok when wandering in the jungle one day fell into a large hole in the ground and could not get out again. After a time the timbadou ${ }^{1}$ came to the hole, and seeing the plandok, said, "Why, plandok, what are you doing there?" "Oh," said the plandok, "I've come here to see my mother and father, my sisters and brothers." "Wait a bit," said the timbadou, " and I will come down too, for I also wish to see my mother and father, sisters and brothers," but the plandok told the timbadou he was not to come down. Then the timbadou answered that if he said that again he would fall on him from above, and he, the plandok, would die. So the plandok gave the timbadou leave to get into the hole and the timbadou came down. When he was down the timbadou said to the plandok, "Where are my father and mother?" "Wait a little," said the plandok, "I've lost them just at present." So the timbadou waited and after a time the rhinoceros came to the hole and asked them what they were doing. Then the plandok answered as before that he was amusing himself, that he was seeing his father and mother and that there were lots of shops down there. Whereupon the rhinoceros came down too, "For," said he, "my father and mother are dead and I would like to meet them and see how they have come to life again." Next came the stag and asked what they were doing and the plandok replied that he was seeing his father and mother and that there were many people sailing away on voyages down there. So the stag also jumped down. After that came the kijang, ${ }^{2}$ and he receiving the same answer from the plandok came down too. Then since the other animals were standing on each other's backs in the hole, the timbadou at the bottom and the kijang at the top, the plandok was able to scramble up to the top on their backs and make his escape from the place. Now when he had got out he met a man and his dog hunting, and the dog having got on his scent pursued him. Then the plandok made for the hole and running round it once or twice departed. So the dog, while following the scent of the plandok, came to the hole and seeing the timbadou and the other animals stopped there barking. Then the man came up and killed them all. As for the plandok he got off scot free.

\section{A Slightly Different Legend of the Beginning of the World.}

Told by the headman of Kampong Timpalung, a Tuaran Dusun.

At first there was a great stone in the middle of the sea. At that time there was no earth only water. The rock was large and it opened its mouth and out of it came a man and a woman. The man and the woman looked around and there

1 Timbadou, wild cattle.

2 Cervulus muntjac. 
was only water. The woman said to the man, "How can we walk, for there is no land ?" They descended from the rock and tried to walk on the surface of the water and found that they could. They returned to the rock and sat down to think; for a long time they stopped there; then again they walked upon the water and at length they arrived at the house of Bisagit (the spirit of small-pox), for Bisagit had made land though it was very far away. Now the man and his wife were Kenharingan and Munsumundok. ${ }^{1}$ They spoke to Bisagit and asked for some of his earth and he gave it to them. So going home they pounded up the rock and mixed Bisagit's earth with it and it became land. Then Kenharingan made the Dusun and Munsumundok made the sky. Afterwards Kenháringan and Munsumundok made the sun as it was not good for men to walk about without light. "Then," said Munsumundok, " there is no light at night, let us make the moon," and they made the moon and the seven stars, ${ }^{2}$ the blatek (spring trap) ${ }^{2}$ and the kukurian. ${ }^{2}$ Kenharingan and Munsumundok had one son and one daughter. Now Kenharingan's people wept because there was no food. So Kenharingan and Munsumundok killed their girl child and cut it up, and from the different portions of its body grew all things good to eat: its head gave rise to the coconut, and you can see the marks of its eyes and mouth on the coconut till this day; from its arm-bones arose sugar cane; its fingers became bananas and its blood padi. All the animals also arose from pieces of the child. When Kenharingan had made everything he said, "Who is able to cast off his skin? If anyone can do so, he shall not die." The snake alone heard and said, "I can." And for this reason, till the present day, the snake does not die unless killed by man. (The Dusun did not hear or they would also have thrown off their skins and there would have been no death.) Kenharingan washed the Dusun in the river, placing them in a basket; one man, however, fell out of the basket and floating away down the river stopped near the coast. This man gave rise to the Bajau who still live near the sea and are skilful at using boats. When Kenharingan had washed the Dusun in the river he menghadjied $^{3}$ them in his house, but one man left the house before Kenharingan had menghadjied and went off into the jungle to search for something and when he came back he could not enter the house again for he had become a monkey. This man is the father of the monkeys.

\section{Pots.}

\section{Told by a Dusun of K. Tambahilik.}

A long time ago men had no cooking pots and when they wished to cook they had to use bamboos. One day a youth went out into the jungle with his dog to hunt, but the dog would not hunt and kept stopping. So the youth, wondering, went to look why the dog had stopped and saw that there was a small mound. $\mathrm{He}$

1 Chief gods of the Dusun.

2 Constellations.

3 Menghadji, to perform a religious ceremony. 
scratched in the mound and taking some of the earth, which was potter's earth, he took it home and told the women to make pots of it. When they had finished making the pots they found that they were useless and fell to pieces. "Ah," said the youth, "this will not do." So going back to the mound he made a large hole until he came upon sand. Then he took both sand and potter's earth and coming home again told the women to make pots. This time the pots were good and thus pots are made to the present day by mixing sand with the potter's earth. 